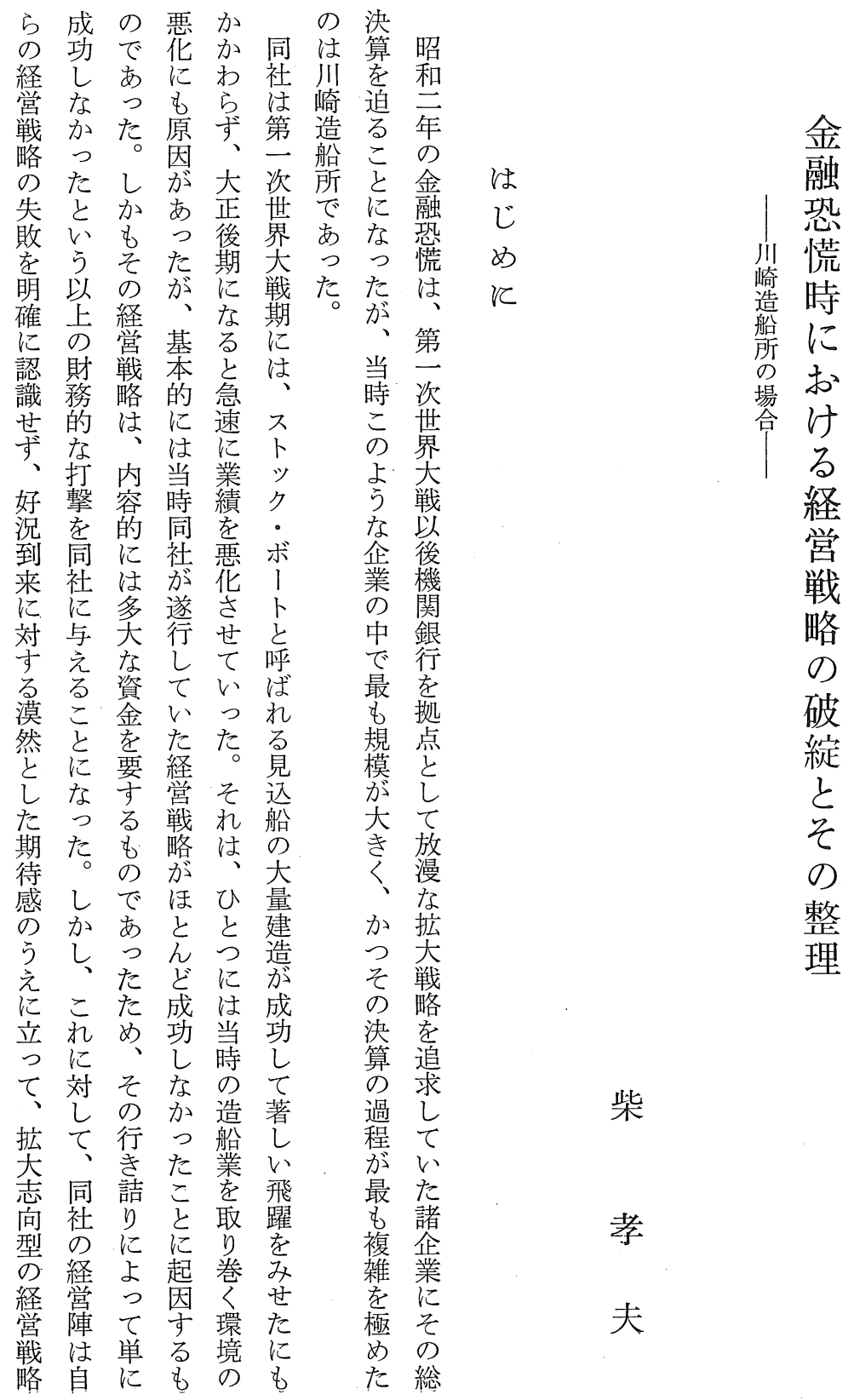


経営史学

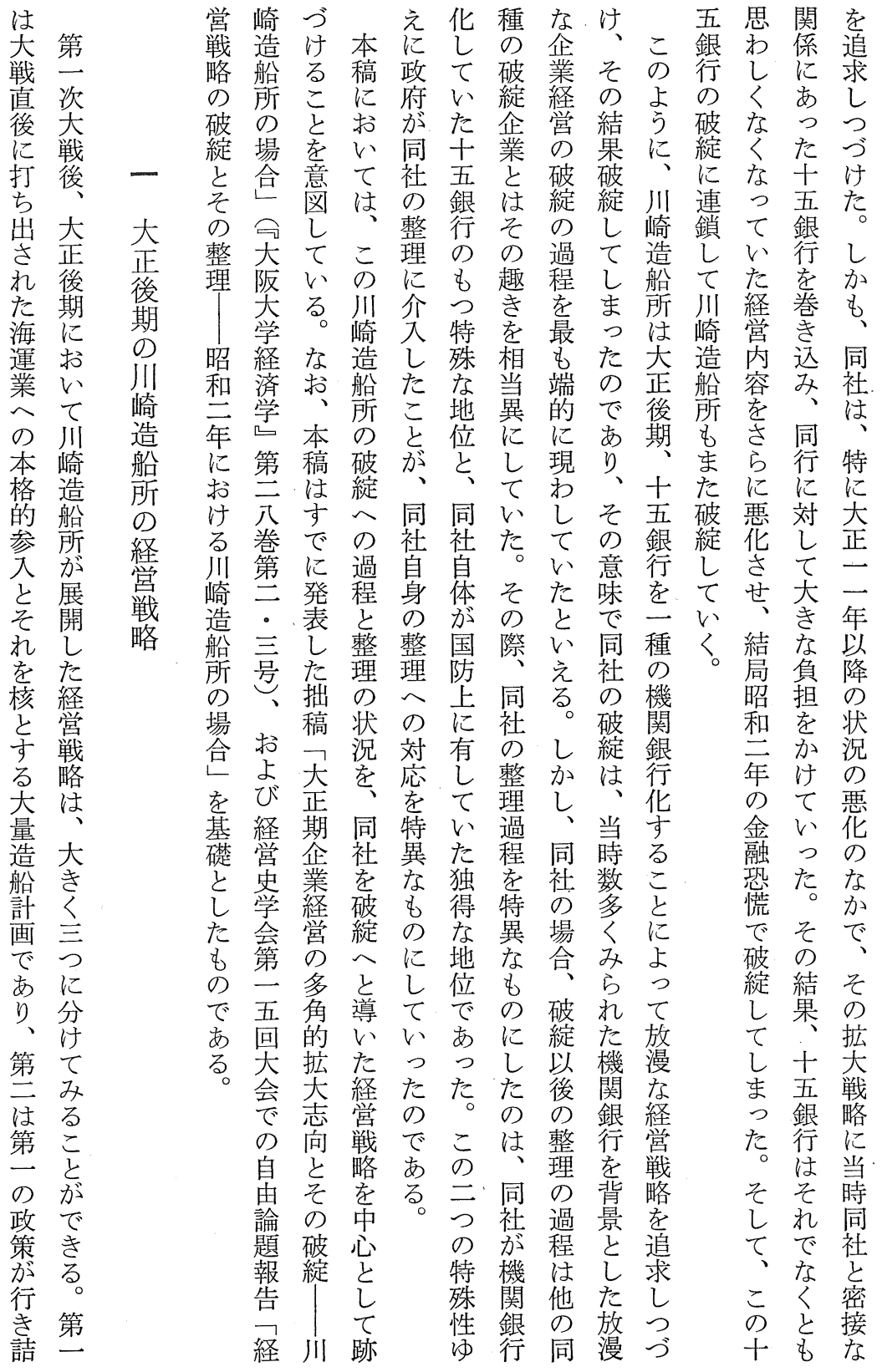


初

う績 社 そ

のあい本

第 1 表 川崎造船所船舶部成績

頭しるを船の同悪るた質

ま, 海踏の背社化。ず的

でし運ま運後がにしらに

長周部え用に第対たには

<知門、と大专古搪ひ

低ののさ量次るっ大と

迷よ創らうの大十て政う

状引設に形造戦分、策の

態にに当で船直な当を共

孝乗時海計後刘然遂通

続大りの運画応の行し

け戦出同部を学こす

た後し社鹏伴すをとる 経

のた社にっ第持とこ営

そ海の長進た方しと意

の運で松出、に光てに識

た界あ方しき遂てこょ加

めのる幸てわ行いれるら

同推。次おめしならて導

社移郎り尗少の新

のはの、野うつ戦た

こ松 海第忍とた。略な

の㘯運1的乞。如展采

海の界表なたそ開た

運自のの経海の第をも

業信先よ嫦運た算はの

乞 䘕う戦業め六少で

のほきに略へ、軍ろあ

進まに相でのこ需うっ

出っ対当あ本机而とた

策た すなっ格らの娄

はくる利た的は適るす

逆満益。進、虑経な

\begin{tabular}{|c|c|}
\hline 決 算 期 & 金 \\
\hline 大正 7 年 5 月 & $2,170,669$ \\
\hline 11月 & $5,272,964$ \\
\hline 8 年 5 月 & $13,926,634$ \\
\hline 11月 & $8,100,327$ \\
\hline 9 年 5 月 & $2,190,657$ \\
\hline 11月 & 599,671 \\
\hline 10年 5 月 & 153,872 \\
\hline 11月 & 49,424 \\
\hline 11年 5 月 & 624,443 \\
\hline 11月 & 367,268 \\
\hline 12年 5 月 & 2,544 \\
\hline 11月 & 535,906 \\
\hline 13年 5 月 & 666,966 \\
\hline 11月 & 311,896 \\
\hline 14年 5 月 & 2,382 \\
\hline 11月 & 41,577 \\
\hline 15年 5 月 & 969 \\
\hline 11月 & 16,631 \\
\hline
\end{tabular}

資料）『エコノミスト』昭和 2 年 7 月

1 日号, 24 ペーシより作成。

始行名をこ出す策営

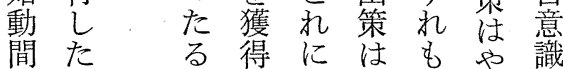
も形自先告や加外結に策さ略策で

なては門結っへま ちつ個拡採戦適過 なで信て立単途性ら部果はでれ上で中 展に心点なで臀生環採そあた記あ心 行開基た。可行意友境用执る飛三る。的

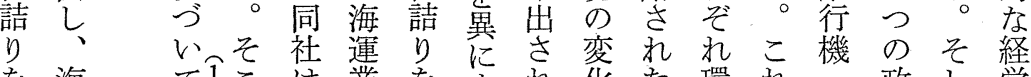

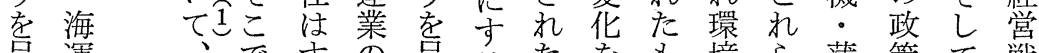
呈運、ですの呈るたをも境ら薄策て戦 す界社同で兼す守も正のの方板唯略 るは船社に営るし、の確で変つ製行後と よことは大でよばにあ化の造きにな うの、戦はう外っ把っに経等詰同っ に後対こ中なに部た握た対営のま社た な昭比のにくな環の势応戦諸っが、軍 っ和し実自、る。境です、、し略部たと需 
経 営史 学

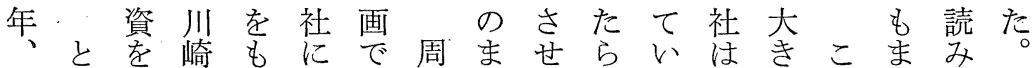

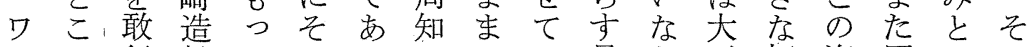
シろ行船てのつののい見加正打海同るの

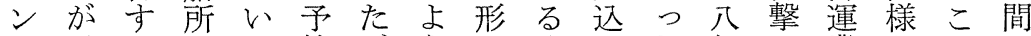
卜るるは算がうでにみた年で業なとの ンここ上との、に温もがかにあへ経が状 軍のと述し多当八存加あら国つの過で況 縮同でのて大時八しかっで際た本を寺き格

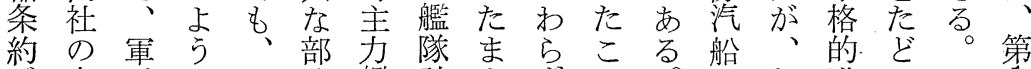
が大需なこ分艦計まずと口方た進つこ1 発戦に海の吕建画、、もま設だ出ての表 效後よ運大振造は軍そそた立当のい他で

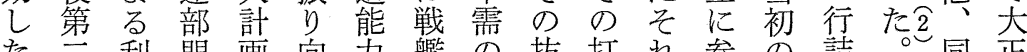
た三利閳画向力艦の抜打れ参の詰。同正 この益のをけを確本撃と加時り 社九

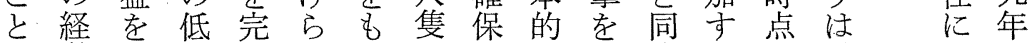

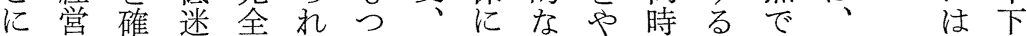
よ戦保市遂る民巡経整わにこは期 つ略しに行こ間洋棠理ら瑟以 てもよむすを造戦のを垱当でだ後学 八十分と少た ほ 八なしわめぼは隻を拉果軍の的価前社

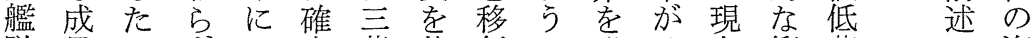

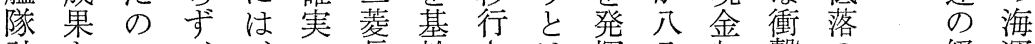
計をで、索長幹さ揮八収撃の経運 画ああ大設 あ崎とせ艦入文な 営部 がげる点正備つ造しるなた隊を同か 戦門 廃る。九厹出船てこ加。計得社で 略の

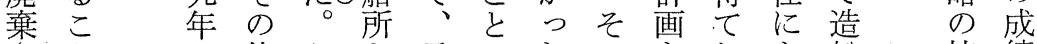
さと加と他と予でた の学おすも船核績

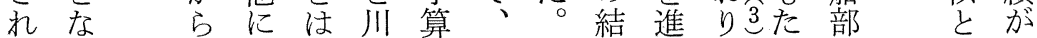
たく 一新い崎嫢こむ果め、ら門し極

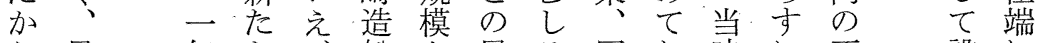
ら早年な船七局ろ同お時に不設に で期に拡た所億面同社り振立低 あに加充との六を社は、財至に不 る挫投光み一打は海そ務ら直挃し

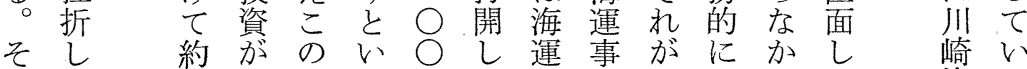

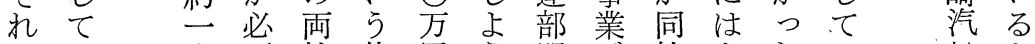
にし 要社状円う閏社またい船と 伴ま ○で驾洗にとでそにだ。た

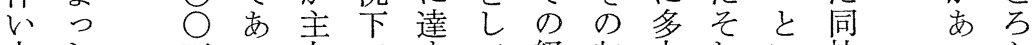

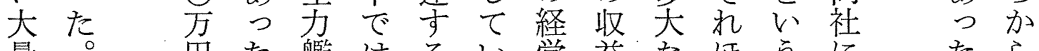

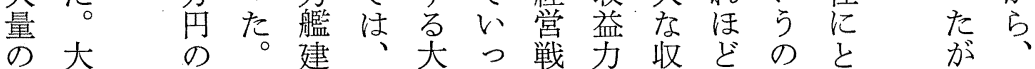

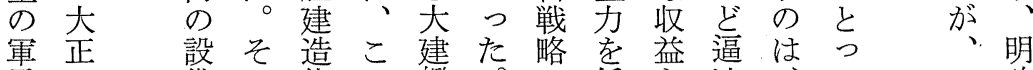
需二正こ能の艦。低を迫確

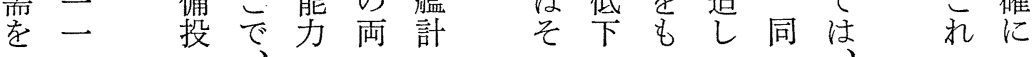


第15巻 第 1 号

達投る。

て 資し大

次金加正

た多 \& 二

の回、○

で收同年

、不社末

先能 がで

の亡先す

船なにで

舶つ自に

$\sim \tau$ 社 三

の 以船 四

投た学学

資こ物 万

金の 出円

之両資に

合 社 し達

わへたしたいしかか社きかっ折

せの川て

る出崎

と資汽た

同忙

社、国こ宁

の大祭 れ

大正汽 が

正一船々

二○のの

$\bigcirc$ 年 両ま

年末 社ま

末 の \& 海

の川業運

資崎績不

固 船 覀

定所 化

額 のさ

は簿 世定吕

約価て 化

九でおし

○はりて船

約

$\bigcirc$ 五

万四

田的た午

近 $\bigcirc$ 加

く万はら

に円そで資

達にのあ金
第 2 表 川崎造船所未処分ストック・ボートへの投下資金額

(単位 円)

\begin{tabular}{c|c|c}
\hline 年 度 & 投 下 金 額 & 同 左 累 積 額 \\
\hline 大正 9 年以前 & $6,164,309$ & $6,164,309$ \\
大正 9 年 & $11,008,813$ & $17,173,122$ \\
10 年 & $16,869,760$ & $34,042,882$ \\
11 年 & $4,139,699$ & $38,182,581$ \\
12 年 & $2,669,375$ & $40,851,956$ \\
13 年 & $2,021,140$ & $42,873,096$ \\
14年 & $2,781,732$ & $45,654,828$ \\
\hline
\end{tabular}

注）1）本表は各年度に建造された未処分ストック・ボートの実際原価を集 計したものである。

2）未処分とは売却むしくは現物出資されずに同社船舶部所属になった ことを意味する。

資料）川崎重工業株式会社所藏「会計資料」および川崎造船所各期営業報告 書より作成。
たたつのらは好つた折昨を失 第のとな船完大転た。た述にた 2 ではが舶全戦をこそがのな同 表あいる供に中見との、社

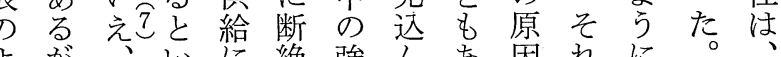

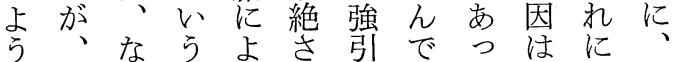
にこ峦っれないた既よ同 れ海情ててスた方述っ社 同は運もない下こ、のては 社迥進あんた ととなた 方社出つとたのク机うだ戦 この戦た加貌。重とにち直 の財略仕、ボ要同同に後 政務とそ事々 | な時社そに 策にその量の影にのの打 に重れたを海政響当経計ち し大にめ確運策妾時営画出 な付同保部に与な另のし 負随社し閳よ方当放た つ担しはてのって松初棄海 てた当い整てい方放学運 公造初た理、た社机行業 た船の造は他。長ほなへ ら計計船そ系し茂どおの

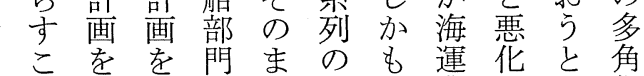
亡維多の安海、業しは化 に持少縮同運当のてしに

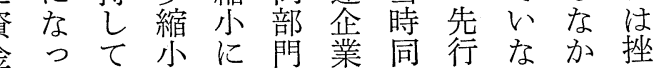

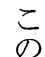

時

点

で

財

務

面

か

5

挙

に

危

機

的

次

洗

に

追

w

क

5

れ 
経 営 史 学

第 3 表 川崎造船所の固定資産（船舶を除く）の推移

(単位 1,000円)

\begin{tabular}{|c|c|c|c|c|c|c|}
\hline 年 度 & 地 $^{1)}$ & $\begin{array}{ll}\text { 家霖 } & \text { 物 } \\
\text { 構 }\end{array}$ & $\begin{array}{l}\text { 器 械 } \\
\text { 特 許 } \\
\end{array}$ & その他 ${ }^{2)}$ & 計 & $\begin{array}{l}\text { 対前年度 } \\
\text { 増 加 額 }\end{array}$ \\
\hline 大正 8 年末 & 9,979 & 4,673 & 7,938 & 1,919 & 24,509 & - \\
\hline 9 年末 & 11,691 & 5,558 & 9,566 & 2,105 & 28,920 & 4,411 \\
\hline 10年末 & 12,343 & 6,794 & 13,654 & 2,376 & 35,167 & 6,247 \\
\hline 11年末 & 12,263 & 8,133 & 16,256 & 2,375 & 39,027 & 3,860 \\
\hline 12 年末 & 12,155 & 8,551 & 21,146 & 2,462 & 44,314 & 5,287 \\
\hline 13年末 & 12,156 & 8,831 & 22,670 & 2,492 & 46,149 & 1,835 \\
\hline 14年末 & 48,706 & 9,078 & 24,679 & 2,584 & 85,047 & 38,898 \\
\hline 15年末 & 48,738 & 10,516 & 33,233 & 2,979 & 95,466 & 10,419 \\
\hline
\end{tabular}

注）1） 14年の異常な増加は同年再評価がなされたため生じたものである。

2）「その他」とは「雑具」「船架・船渠」「構内鉄道」「造船台」をさす。

資料）川崎造船所各期営業報告書より作成。

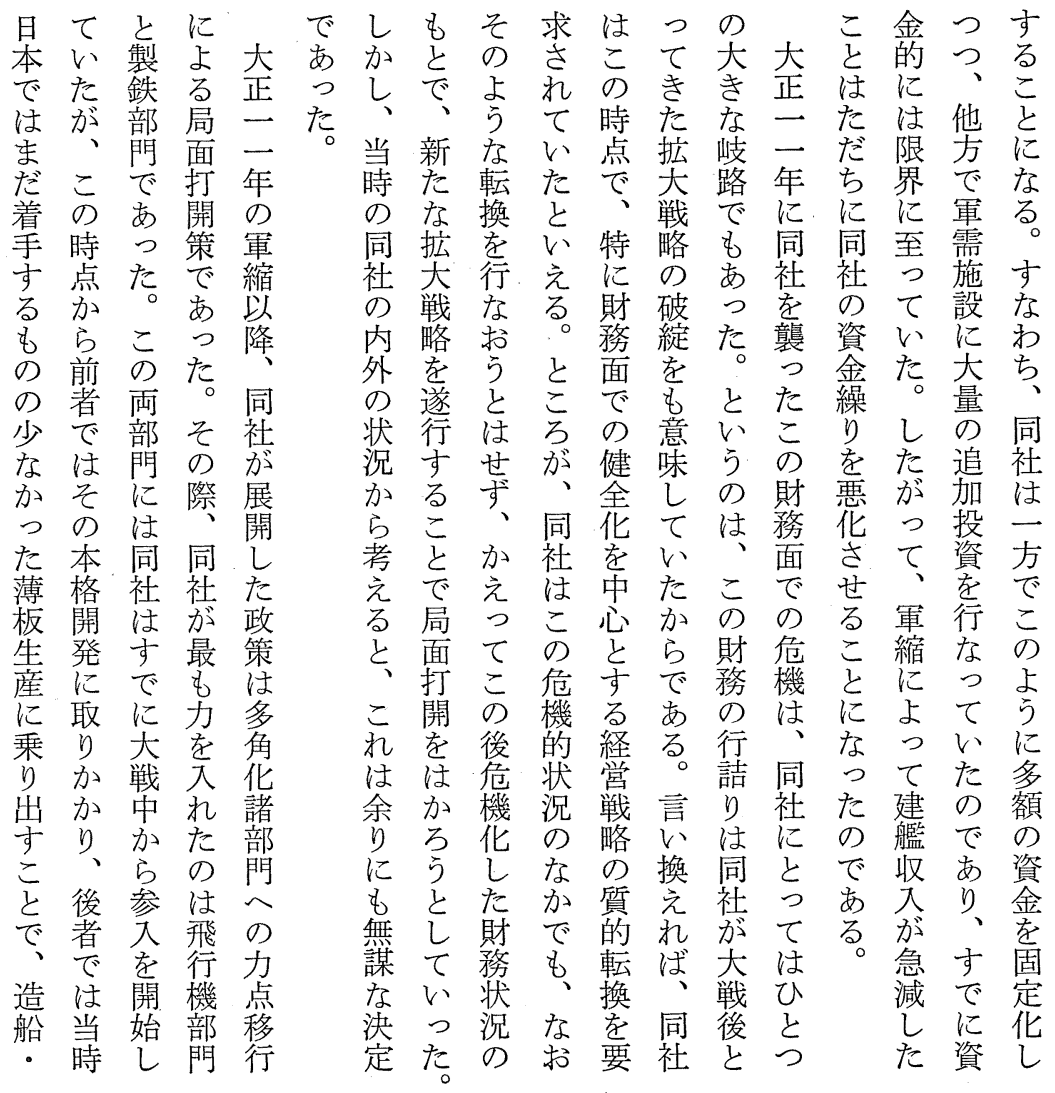


第15巻 第 1 号

たしは同たへ維秝

のたこ社こめの持ば

は経のののに期しな

、嫦経財よと待よら

当戦党務うらをるな

時略戦状にれ捨と加

同は略況、たてしっ

社結至は軍方きたた

と局遂既縮策れた

密同行述以でずめそ

接社守の後あ、、机

なをるよのっそこに

関外たう同たののの加

係部めに社が留面

を金に逼の、にで

保融外迫政しはも

持機部化策汃人大

乙関吕しはし員量

てららてこのの

以の大拉の解運

た依量りに時雇転

十存の、多点等資表

五に資こ額での金の

銀 導金ののは造をよ

行いを資資い船必ら

でて 導 金 金た 部要

あ、入を投ず閔収

つっせ自卡らのし益

たた称兮を縮て兄

のばで要出小いが

でな. 供方費がた相第にでは階し海

あら給るを重。当 3 ああ的運

るな尔む拡 大こに表りつなあし耐

○古の大なれ低のなた拉つ、部

そつ力で专損は下よが。相たこ門

のたをある失こしららて当たのの

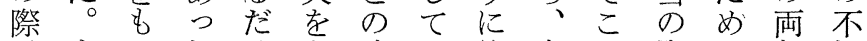

すつたけを時い約大で資、部振

同なてのでた点た九正、金こ門を

社わいであらで造 $\bigcirc$ 一同投れは補

がちなあっすを船 ○一社下ら同完

最、かるたと、部万年はにに社し

も軍つが、心松門丣か既よ力によ

大縮た、ら方をのら述る点とう

き以。判が、設—の設をる

々後そか断なな備三云備移てし

依、のし㧧投年う市行はた

存同たこ示海整資にな拡专ます

し社めの運理孝か財充るだで

てが、時て界せ行け務孞た開あ

心展同点 
に浪良る備第光傾す広と維 の信行た そ速貸と率 5 てはたげこし用の後五 の銀出こ六表およめてろてを株も銀 貸行をら三にりりのそが、同主、行 出 態、数端をらそく金規大。ははの周 度合抱的維れれな量模正華創知 は併えに持るをっとを期つ族立の 放直て現し占た支拡に范当よ 漫前いわてう併。店大入 なにたれ沶ににと網しる

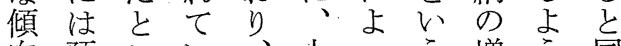
向預こい、十っう増う同 を金らるな五ての大と行 も注找銀十はをしは っ億あう健行五、理たし て公っに全の銀こ胄ただ

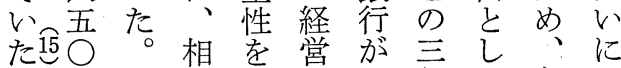

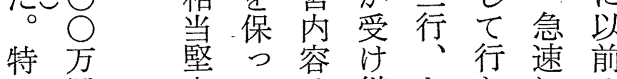
败実て言継となにの 当擁学た大市わた出の族 時卞な加戦し 讨堅銀 のるく、期ま浪浪実行

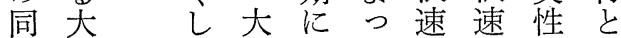
行銀て正入た の行 $、$ 九加神行失て 頭でた年てら六、っの 取あ㐫のかで川神て1 加っこ合らあ崎戸いメ 松た の併やる。高崎た产流

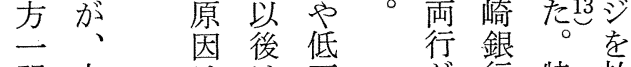
門大注莎行特払 の戦浪支し そ抒に拭 四中速払たのよ大寸 男に・準と経び正る 松急神備は.営丁九よ 方速憵率呙酉年引 正に川㤎穴銀、に 雄業崎三百行経な

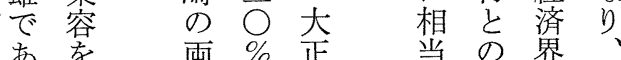
あ考画\%正当采界多 た大㠰に年き併膨方 こし い下で、な張面 亡たかがも問後にに かだゆつ支題之即融 ら汀るて払をの応資

多初亏

䣄

繁事に 行

でう情明

あてか治

るおら り わ $\bigcirc$ 造 そ、架船 れま国に所 だたの華 け宮金族 に内融資 同省界本 行金, に老 は庫一結 少々種集 なう殊た く特な国 之典地立 \& 安 位 銀 明付を行 治与保々 期さ持し に机儿て 打てて発 いいい足 てたたし はた金明 き, 機治 わ華関

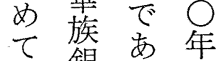
堅銀っに 実“た行た なと経とす銀 営しな行 方ておに 針独占、転 
第15巻 第 1 号

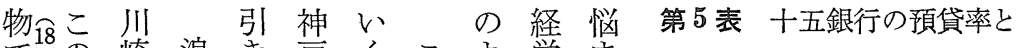
での 崎 浪ききたこよ営ま

関正速継川このうがさ

こ係蔵銀夯崎のよに相れ

ののの行れの過う自当て

二発個とて両程に身压い

人端人川W行怕

はで企崎っがま十経さ

支払準備率の推移

後あ業造た川た五営れ要

(単位 \%)

\begin{tabular}{c|c|c|}
\hline 年 & 預貸率 & 支払準備率 \\
\hline
\end{tabular}

につか船か崎同銀内呙方

とたら所ら造行行容いる

もの株がで船とはをたに委た 7 年

にで式相あ所川大悪の

\begin{tabular}{l|l}
107.6 & 98.1
\end{tabular}

92.9

98.5

浪 あ 会 互

速る。社に

行 そ改接

のの 組 な

頭 際さ関

取狆係

を取たに

つ締方入

と役、っ

めにそた

た就のの

人 任 時

たし初

ちた代早

での取く

あは締文

つ野 役 明

た鱼元 䮨 監

ると崎正华でこ

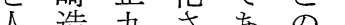

83.6

90.8

年

80.5

73.5

79.1

66.7

85.2

62.7

人造九さ

92.4

31.3

的船年せる。 13年

99.7

32.6

に所のた。行

98.1

29.6

\& が ここしと

取 密行亡た文

引接と注々

14 年

99.2

29.7

15年

100.3

30.1

面にの当つの

注） 各年下期決算の数字。

で結 合 然て 取

資料）日本銀行「十五銀行/破綻原因

及其整理」（日本銀行編『日本金融 史資料・昭和編』第 24 卷） $482-489$ -

密づ併の 文

ージより作成。

接 い契亡併係

なて機でにのそ大固不運多大

関いにあよ偏れ戦定況企数口

係く以つつりだ期貸の業存貸

を過前たて㤎けにとな加在出

も程の。こ貸に船なか多し先

つで健の出海舶つでかてに

て 全三の運金て業つおは

乙、查十

加監役 九

女, 查に 年

前に行こ

の任係で

野し者亦

元た がっ

はの 云た

こ吕人

打あ性

りっを

行固企融い績たり、そ

、た失

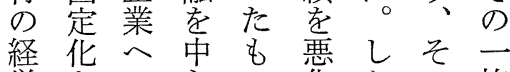

そとて

がいい

営をの心の化かの族

の 外 参 同

後 背加年

長造た 崎

队 5 ○

はのた

りはが

併同同

に行行

内招貸と额さも他の

容い出し多せ、に関

老て㠰てくてこ住

よ が が

○合 健

て 併 全

十七性

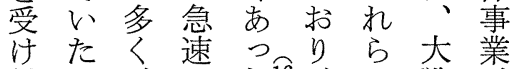

継の、㑔、西、の戦

いでこ取。実企期い

だあれ引ま質業にわ

十りを関た的の急ゆ

くここ造

川文船

五た学

崎う。台所

銀 浪 失

行速 つ

五、固係神に多速る

銀々定を倿くに薩 行れ貸拉川回流成州

がにの大崎収大長采

造人、注

に・

上増 ᄂ 銀困 戦

先つ加た行難後た業

述てに染はのの海㤎 
もた合の併らうつ正うっ足潤的陣正船 ま副併ににこなにて期またをを関に所 た頭前すよの関大、学をた来得係参年取 長取後るつよ係戦結通、でしたが加か締 くでに条てうか中びじ神あたた密しら役

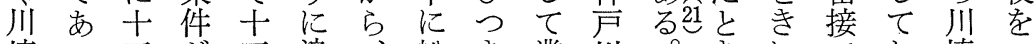
崎つ五吕五浪、船き業川导にでお崎ら 造た 銀存銀速当舶加務崎 には文り、造亡

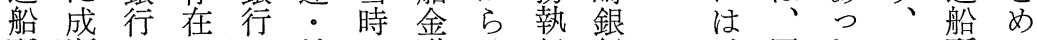
所瀬のしへ神の融い行行们た 同た所て の正頭ても户淁を社は浪社だののお

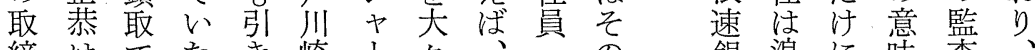

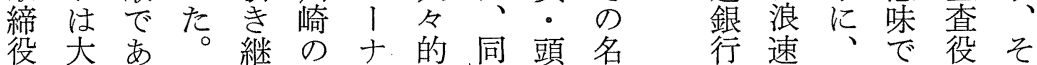
の正つそ驾両り行取㤎柺銀ここにの 席入たれれ行ズ行は学示五行のの就在

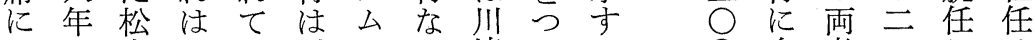
あに方やい川はつ崎とと多者つしは つ川撖注く崎同て造めお額の おて昭 た先崎は、りこ造行お船てりり、

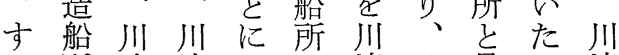
な所崎崎なと崎と最の崎 わの造造つき造のもは造 ち監船船たわ船面近、船 、查所所がめ所で、川所 十役社と、て の 卢位崎 の 五に長同一親機川置造創 銀就の行方密関崎に船設 行任松の、な銀造あ所者 のし方経十関行船つので 側て幸営五係と所た 副あ のい次陣銀に見と金社っ こた郎間行あなの融長た の。ににのつし結機で川 よさと存 側たてび関も崎 うらっ 在での い23つであ 正 なにてしもでた包きあつ蔵 条こはてこあたはこた 件の実いのり 深た 川よ 加成兄た 閶、、加。崎つ 浪のあいをた放太創

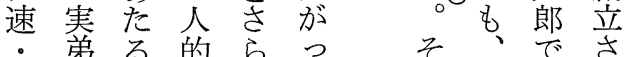

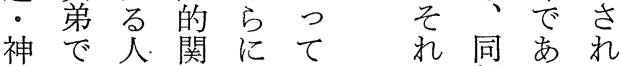
神六物係密こゆ行つた 川るでで度の 崎成ああの関 両 瀬りつ濃 係 行 正、た え既た 銀 円近預引聚 企 金関 の 融学係人すに 通行安的なま をなま関わで 行、た係ち、至 な、親は浪て てた岀゙わ速い そ大戦つめ銀た。 そ戦っで行密の を同。接歴た 補社たで代 完肪とあ頭大 寸海えつ取正 る運ばたの期 なへ、のらに ジの大でち同 、多戦あ文行 相角期る人頭 互化に。ま取 にに川しでで 支伴崎かがあ 援つ造も, 川つ して 船、崎た あ 流 所こ造 松 う動 がの 船 方 関 資 厐よ所 正 こ述しで係金大うの雄

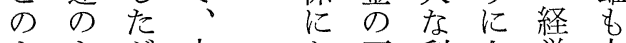
よよ肪大市不利人営大 
第15巻 第 1 号

第 6 表 大正後期の川崎造船所の負債の推移

（単位 $1,000 円 ）$

\begin{tabular}{|c|c|c|c|c|c|}
\hline 決算期 & 支払手形 & 社 債 & 借入金 & 川崎汽船勘定 & 計 \\
\hline 大正 9 年 5 月 & 16,778 & 8,850 & 100 & 9,570 & $35,298(100)$ \\
\hline 11 月 & 19,423 & 8,450 & 100 & 8,446 & 36,419 (103) \\
\hline 10年 5 月 & 20,678 & 7,850 & 100 & 7,768 & $36,396(103)$ \\
\hline 11 月 & 20,667 & 4,800 & 100 & 8,174 & $33,741(96)$ \\
\hline 11 年 5 月 & 34,285 & 3,000 & 100 & 8,206 & 45,591 (129) \\
\hline 11 月 & 28,349 & 9,850 & 0 & 10,303 & $48,502(137)$ \\
\hline 12 年 5 月 & 27,431 & 18,500 & 0 & 10,095 & $56,026(159)$ \\
\hline 11月 & 36,032 & 27,000 & 0 & 10,623 & 73,655 (209) \\
\hline 13 年 5 月 & 38,209 & 35,000 & 0 & 10,569 & 83,778 (237) \\
\hline 11 月 & 42,073 & 44,000 & 0 & 10,548 & $96,621(274)$ \\
\hline 14 年 5 月 & 40,894 & 53,000 & 0 & 9,987 & 103,881 (294) \\
\hline 11月 & 54,273 & 51,000 & 0 & 10,823 & $116,096(329)$ \\
\hline 15年 5 月 & 57,422 & 60,000 & 2,000 & 9,649 & $129,071(366)$ \\
\hline 11 月 & 67,137 & 58,000 & 3,650 & 7,485 & $136,272(386)$ \\
\hline
\end{tabular}

注） 合計蟠の（）内数字は大正 9 年 5 月を 100 とした指数を示す。

資料） 川崎造船所各期営業報告書より作成。

い貸三とな先を支月縮て関きこにの た付年は資行示払に第に以は係わの強合 残に考金き苸約 6 危後いはめ合固併 こ高十えをを資形一表険もな当て併なに のは五に供不料の三にななか初強の立よ 金、銀く与安は堌○み関おつ時のつ 額 第行い军視、加 $\bigcirc$ 係抾た取な期にて は7 が。るさ現分万れへ大。引結かすす 第表破一金れ在坴円ると戦し的びらるる 6 の 綻方融ての究強よ転略加につ川役こ

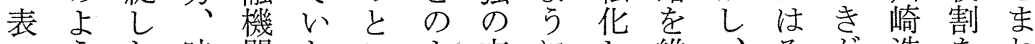
のらた時関たこよ支にし維、を方造をれ 川に時間方同らう払、て持既れ生船果た 崎約点的そ社存な手川いし述ほほし所た川 造四でにれに在経形崎っよのとてとし崎 船四のほほ対し路を造たうよ大い十た造 所 $\bigcirc$ 同やどしなで増船。とうきた五の船

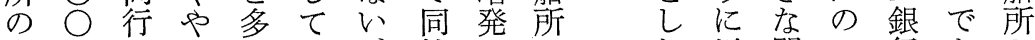
大万の隔く、が社しは問で行あと 正円対た存こ、驾て大頃崎題市とる。 十に川る在れ軍処い正加造をるの。関 五の崎がしほ縮理た二船発が間そ係 年ぼ造、てど以し、所生、結を 末つ船昭い巨後たこ年してがさこは結さ 時て乺和た額の夰の五 た軍せの果ら 
経 営 史 学

第 7 表 十五銀行の対川崎造船所貸付金概算内訳 手 川 先 五川 点 (昭和 2 年 6 月現在)

形と崎の 銀 崎 で

(単位 1,000円)

をは造軍行汽の

こ船 縮 借 船 支

れつ所直 大勘払

ほては後金定手

ぞもこのは以形

カーレント貸付金

2,830

5,000

の川支外の

別口担 保分(注)

8,300

大 、

27,830

にの

発資加船支割

手 形 貸 付

43,960

行 金 ら所 で払以

注）これは川崎造船所が海軍より受領する建造艦艇の代金を 見返りとして，十五銀行が日本銀行より特别融通を受け，

それを川崎造船所に貸し出したものである。

资料）三井銀行所藏「十五銀行重役会議事録」より作成。

しの十の処手上

七使五异理 形索

も途銀額さ点占

そお行なれ借め

机穴払い金い

はけさた負拡支を大こを既同手たのる

るれのす担大払反正の返述社形と項

昭とたはでを戦手映一支済のののみ 自第

和こ飛、に吕略形し二払しよ拡相なし7

初ろ行同みけをにた年手らら大当亦かか表

頭ま機 社たる継よも下形るな戦大厺なで

にで・のよこ持つの期を目同略きをとは

入に薄多らとしてで以社途社のなが、内

つは板角にによ二あ降債は学財部でし 訳

て至の化、なう時つ、に同収務分きかが

から両部こつと的た社よ社益的はるる 種

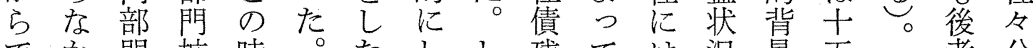

でか門拡 時。たしし残て は況景五し者分

あっの充期 この加高長当加と銀たの品

りた成策の と元しが期時らし行だ金れ

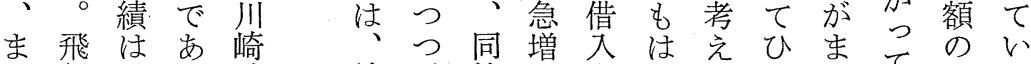

た行、っ造、結、社し金やるきかる

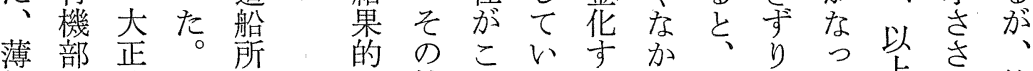

板 鹏 後し の

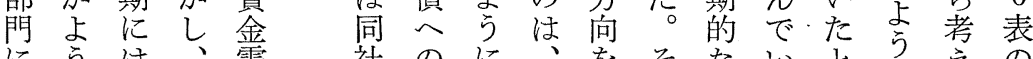

にうは、需、社のに票をないとをえの

乙やつこ要市転軍同とこ性つ考条る川

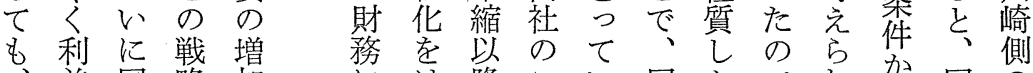

益同略加江降こい同汃でれ方同少

安を社にのさかののく社もあるる

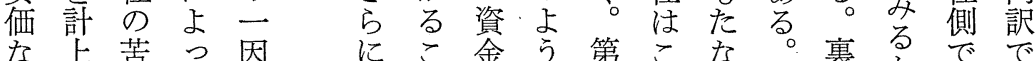

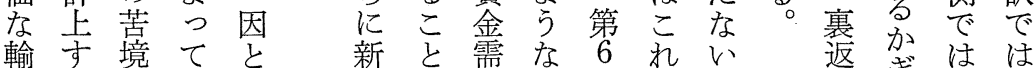

品の学拡な 
転当問部に压表い明堌かく行は不と 資然題分とこ力 II

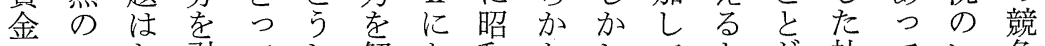
のこな引てし解あ和なしてと社てい争

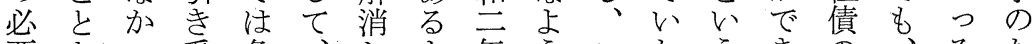

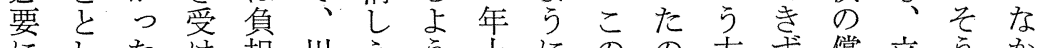
にしたけ担川えら上にのの方す償立う加 迫てがての崎なに期、よ法、還ちので ら支、いよ造い、に同う、を結圧直深収 れ払川たり船状同は社な同繰局力る化益 て手崎。い所態社、の借社り、とこは的 お形造そっはでは新社入の返同利とまに りへ船のそ大あ昭規債金こさ社子はすは 、の所際う正つ和社ににの祀は支なまほ

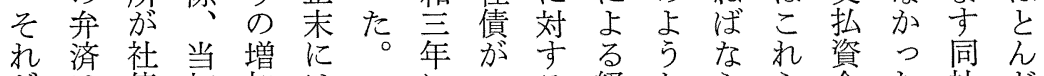
䖞は債初加はこる経なららら金た社ど ま困関のを完 はれ利棠苦なののののの み た難係よ意全々さ子の境加資必で収る 支とのう味にの爫維につ金要市益べ 払な支にし社势字償持よた を学る。力き 手ら払同て債込ま還はるる。再、永を 形ざに社い発資かに、も第び容し減の のる新架た行本な要同の 6 支赦か少が 増を規こ金い守社で表払なしさな 発得社のす悪六切るのああで手く をな債支で循七れ資財つ形同そてっ 招かの払に環五な金務た。大で社れいた

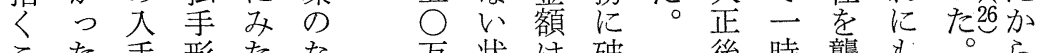

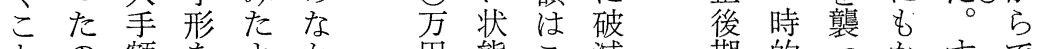
との 額孝よか 円態こ滅期的つかすで にはの社 5 のにの的ににてかなる な当か債に入約至よ結同調いわわわるす⿹ 然なに同り たでり お行こ 第つ部吕川で 6 表。分を崎い 表じ害て造た 同かりる所で 社も、当が支る 大川秝り払吕 正崎ばは手 末造な 同形こ 支所な行相は 払はくと当当主 形おるてき銀 残運とはな行

四つ亏末

割てなを

のい過 \&

資た程た 金ののら をでなす 調 あ か こ せ達る。゙ と ねさ己な ばら増つ こ付的た の佮的第 社守増 8 債 れ 加表 関ばしの 俰、、I の同つで
社達つ号。

支ったす、麦台 热つそ同縮も 形さに吕降軍 と 5 加先同縮 社に。述社以 債こてのの降 のれ、借経の 残を運入党造 高社転 金は船 ほに金策要海 ぼよのに化運 併っ調よ卞両 行て達つる 部 的お法てこ鹏 にき欠発との 
経営史学

第 8 表 大正後期川崎造船所の社債関係要支払額および新規発行による獲得資金額

I 大正 9 年 昭和 2 年上半期までの実際額

(単位 1,000円)

\begin{tabular}{|c|c|c|c|c|c|c|c|c|}
\hline \multirow{3}{*}{ 年 } & \multirow{3}{*}{ 度 } & \multicolumn{3}{|c|}{ 支払社債利息 } & \multirow{3}{*}{ 年償還額 } & \multirow{3}{*}{ ( $\stackrel{\text { 計 }}{\mathrm{A}})$} & \multirow{3}{*}{$\begin{array}{l}\text { 新規発行额 } \\
\text { (B) }\end{array}$} & \multirow{3}{*}{$\begin{array}{l}\text { 実際手取額 } \\
(\mathrm{B}-\mathrm{A})\end{array}$} \\
\hline & & \multicolumn{2}{|c|}{ 各決算期別 } & \multirow{2}{*}{ 年間支払額 } & & & & \\
\hline & & 5 月期 & 11月期 & & & & & \\
\hline & 9 年 & 315 & 288 & 603 & 1,000 & 1,603 & - & 一 \\
\hline & 10年 & 278 & 255 & 533 & 3,650 & 4,183 & - & - \\
\hline & 11年 & 142 & 188 & 330 & 1,950 & 2,280 & 7,000 & 4,720 \\
\hline & 12年 & 483 & 755 & 1,238 & 2,850 & 4,088 & 20,000 & 15,912 \\
\hline & 13年 & 1,181 & 1,493 & 2,674 & 1,000 & 3,674 & 18,000 & 14,326 \\
\hline & 14年 & 1,774 & 2,076 & 3,850 & 3,000 & 6,850 & 10,000 & 3,150 \\
\hline & 15年 & 2,122 & 2,331 & 4,453 & 3,000 & 7,453 & 10,000 & 2,547 \\
\hline & 年(注) & 2,340 & - & - & 9,000 & 11,340 & 10,000 & $\triangle 1,340$ \\
\hline
\end{tabular}

注） 昭和 2 年は 4 月以降同社が正常な状態とはなっていないので，とりあえず 5 月期半期分で集計した。

II 昭和 2 年 6 年までの仮想支払額

\begin{tabular}{|c|c|c|c|c|c|}
\hline \multirow{3}{*}{ 年 度 } & \multicolumn{3}{|c|}{ 支払社債利息 } & \multirow{3}{*}{ 年償還額 } & \multirow{3}{*}{$\begin{array}{l}\text { 当年 度 } \\
\text { 要支払額 }\end{array}$} \\
\hline & \multicolumn{2}{|c|}{ 各決算期別 } & \multirow{2}{*}{ 年間支払額 } & & \\
\hline & 5 月期 & 11月期 & & & \\
\hline 昭和 2 年 & 2,340 & 2,230 & 4,570 & 14,000 & 16,230 \\
\hline 3 年 & 1,953 & 1,419 & 3,372 & 26,000 & 29,372 \\
\hline 4 年 & 1,112 & 1,019 & 2,131 & 2,000 & 4,131 \\
\hline 5 年 & 982 & 629 & 1,611 & 10,000 & 11,611 \\
\hline 6 年 & 628 & 555 & 1,183 & 2,000 & 3,183 \\
\hline
\end{tabular}

注）本表は川崎造船所 の昭和 2 年度の未返済社倩 について, (1)新規社㥽発行 による借り換学がない, (2) 償還方法が同社従来の方式 による, という 2 点を前提 として仮計算したあのであ る。

資料）川崎重工業株式 会社所蔵「会計資料」より 作成。

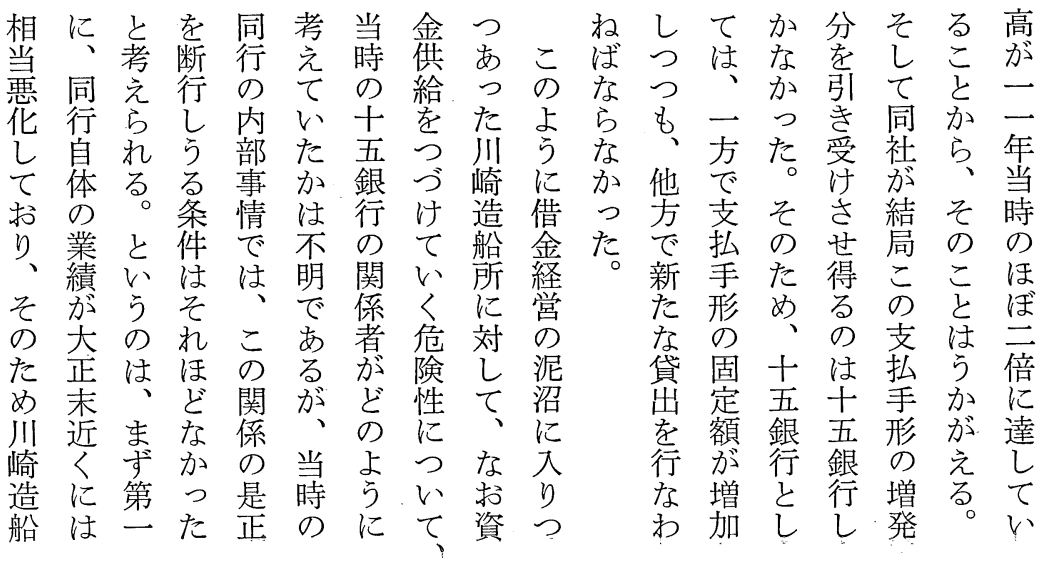


資ゆなの的な五とで利り年不営なな 所

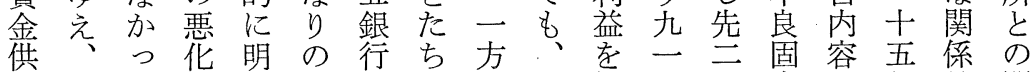
給同たをる 金と它交侵 \% 四定老銀是関 を行と暴み額しこ川く蝕は口貸悪行正係 つのし露にをてろ崎まし何、出化方を是 う関てし出不に造でてら総しさ大断正 け係もてざ損、破船糊い加額のせ正行に て者、しるとそ綻所塗たの三存て九す伴 同㤎当まをしのしのしの形億在い年るる 社も時う得て 既て 側よでで二でっのにて をしのこな計貸しでうあ不五あた。合は予 維こ同とく上出まはとる良 $\bigcirc っ$ 併、想 持の 行にな 世し し川のつるるざ分状既てし出万召後者れ て崎経な。る唯況述いか心経堅間る い造営がすを回にのた采し、化のと営実に同 か船状っな得収あよ。覀性あ 社 水所況ておな不つうう同てち、化装ます ばとでいちく能たに行い、破

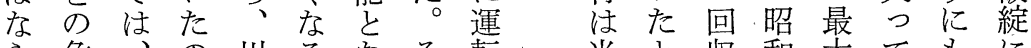
ら危、の川るな転 当と収和大てをに な険川で崎。うう資時い確三云の強耐 かな崎あ造そてな金こわ実年原ついえ つ関整る船のしるのの的との因た人る た係理。所結まと相事てみ亦とこ的力 とにになを果ら。当実いるな本なと関を 考危伴た整党る。先望し銀つは係残 え惧ら、理同し述き可得行たすがし らの巨もに行たのな回こるののであて れ念額し追ががよ部収のも調はにりい

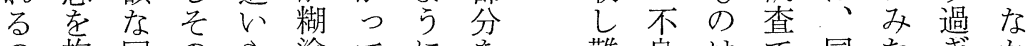
の抱回のや塗て、学難良はで同たぎか で、收よるしい同士貸わ行がたる あた不うこよ同社五利出ず、が、かた

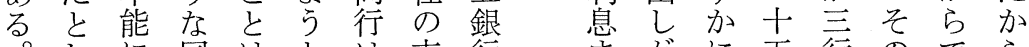
しに同はとは支行は栾染に五行のでら て耐行、しそ払に㢥至銀合結あで もえの十ての手依計行口行併果る あ

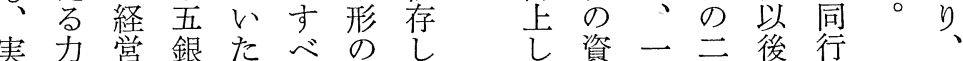
際は内行経て 約て て 金八○多は ま

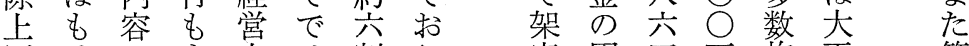
同はのま内は割り、空固四万抱正第

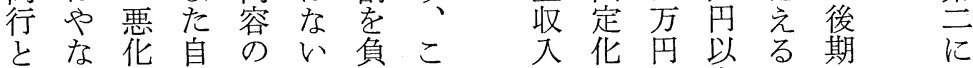

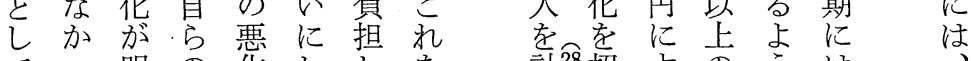

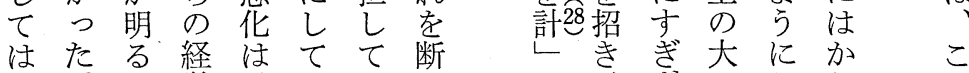

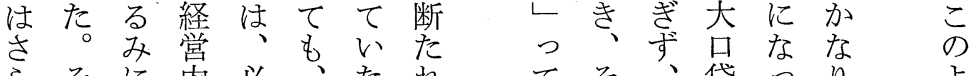

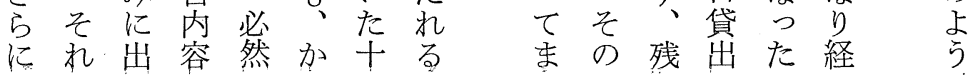


経営史学

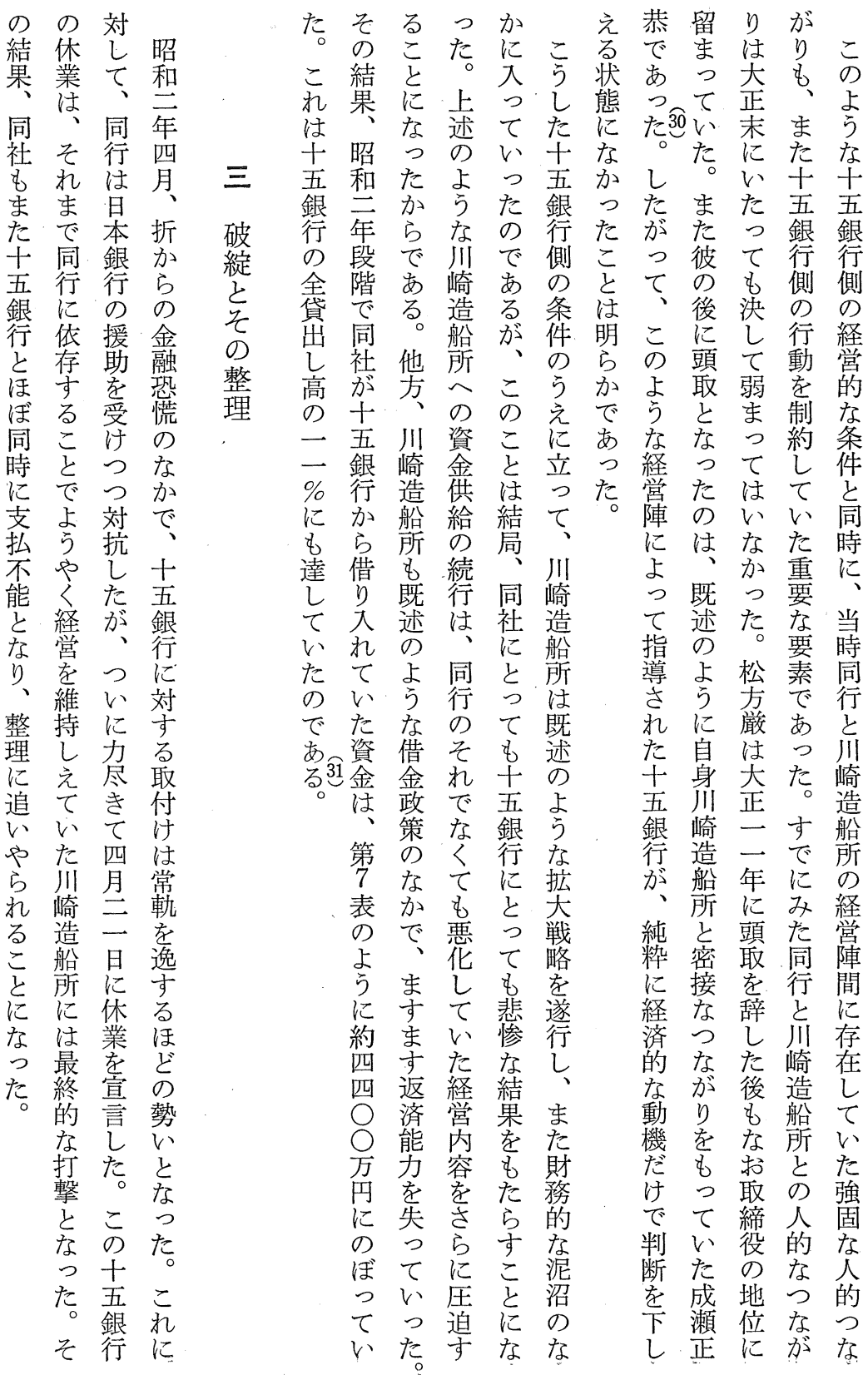


た艦年占体での銀録ええ 川鎖すぐ市

め艇時め制そある行によと崎的るる五前 建 点てののつうの明うこ造な取て 銀項

同造でおな際たな休確とろ船破付疑行で

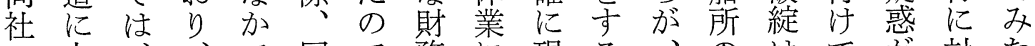

の占、、で同で務に現る、、のはでが対た 経め過こ特社あ面伴わ意破破、 あ生しよ 営る去とに染るでうれ識綻綻実つ主てう 吕比のに重新。の財ては当は際た吆てはな 行重実潜要た行務い希初、に。拉こ十 きか績水なな詰面る薄のこはしりのの五

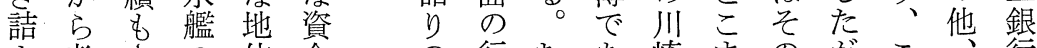
ま考さの位金の行むあ崎ますの祀こ、行 つえる部を源 解詰しつ造で根つれ人と たるこ門占と 消りる、た船士本てらら的川

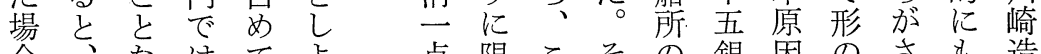
合、なはて 点限こその銀因のさむも 造 は同が海いらう定れの経行もうら取船 海社ら軍たと絞しにこ営を直えに引所 軍の、王。ことと陣引接で金面と が破ま廠すれ理れはにき的は融での

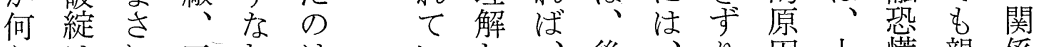

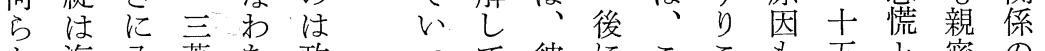
か海八菱ち 政つて 彼にここも五と密の の軍隻造、府 たい老松のん玄銀いな親 形のの船同でなた方よだべ行う関密 で建 艦と社あすこじ幸う同ての異係化

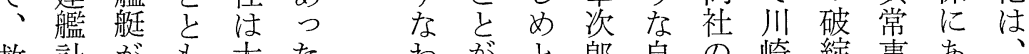
救計 が も 大 た

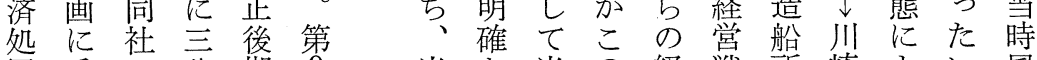
置重 の 分期 9 当と当の経戦所崎よい風 を大船专表初な時破営略か造つわ聞 とな台る通に彼る㝋の綻戦の ら船て ゆと る尔に 状 じ み こ陌 乗 態て ら はもてあ軍るなた嫦事壊のい払机系当

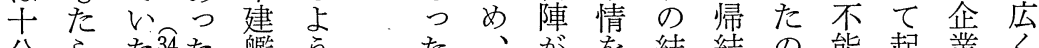

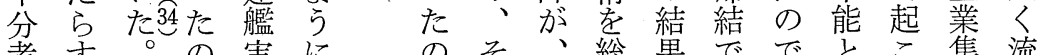

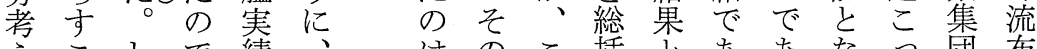
えこしで績、はのこ括とあああなっ団布

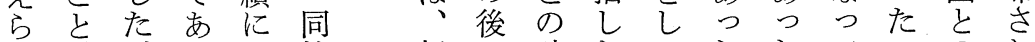
れががる三社 新の破たてたたてののれ

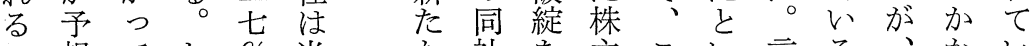

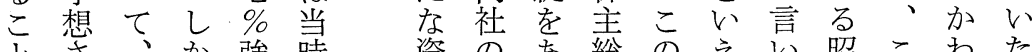

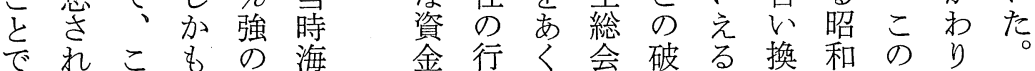

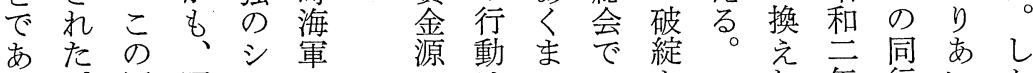

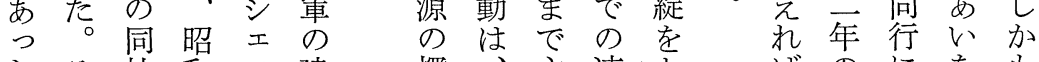

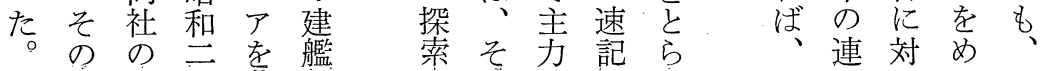


経 営史 学

第 9 表 大正後期海軍艦艇建造量内訳

[大正 9 15年, 進水時基淮，（）内㹥各構成比\%を示す]

\begin{tabular}{|c|c|c|c|c|c|c|c|c|c|c|c|c|}
\hline \multirow{2}{*}{ 造船所 } & \multicolumn{2}{|c|}{ 戦 艦 } & \multicolumn{2}{|c|}{ 巡洋艦 } & 航空母艦 & \multicolumn{2}{|c|}{ 駆逐艦 } & 潜水艦 & \multicolumn{2}{|r|}{ その他 } & \multicolumn{2}{|r|}{ 計 } \\
\hline & \begin{tabular}{|l|} 
檴 \\
数
\end{tabular} & & 隻 & ン盾 & 隻|排 & & 学 & & & 排水トン & 集 & 排水トン \\
\hline 海軍工廠 & 1 & $\begin{array}{r}33,800 \\
(100)\end{array}$ & 4 & $\begin{array}{l}19,740 \\
(19.0)\end{array}$ & $\begin{array}{r}63,300 \\
(100)\end{array}$ & 17 & $\left.\begin{array}{l}22,990 \\
(36.4)\end{array}\right|_{18}$ & $\begin{array}{l}17,335 \\
(37.3)\end{array}$ & 3 & $\begin{array}{l}35,600 \\
(16.9)\end{array}$ & 28 & $\begin{array}{r}192,765 \\
(37.0)\end{array}$ \\
\hline 造船所 & & - & 5 & $\begin{array}{l}30,865 \\
(29.8)\end{array}$ & & 6 & $\begin{array}{l}5,200 \\
(8.2)\end{array}$ & $\begin{array}{l}12,921 \\
(27.8)\end{array}$ & 6 & $\begin{array}{l}92,400 \\
(43.8)\end{array}$ & 29 & $\begin{array}{r}141,386 \\
(27.1)\end{array}$ \\
\hline 三菱造船 & & & 6 & $\begin{array}{l}36,365 \\
(35.1)\end{array}$ & & 6 & $\begin{array}{r}8,180 \\
(13.0)\end{array}$ & $\begin{array}{l}16,182 \\
(34.9)\end{array}$ & 4 & $\begin{array}{r}17,676 \\
(8.4)\end{array}$ & 33 & $\begin{array}{l}78,403 \\
(15.1)\end{array}$ \\
\hline その他 & & & 3 & $\begin{array}{l}16,735 \\
(16.1)\end{array}$ & & & $\begin{array}{l}26,770 \\
(42.4)\end{array}$ & & & $\begin{array}{l}65,196 \\
(30.9)\end{array}$ & 38 & $\begin{array}{r}108,701 \\
(20.8)\end{array}$ \\
\hline 計 & 1 & $\begin{array}{r}33,800 \\
(100)\end{array}$ & & $\begin{array}{r}103,705 \\
(100)\end{array}$ & $\begin{array}{r}63,300 \\
(100)\end{array}$ & & $\begin{array}{r}63,140 \\
(100)\end{array}$ & $\begin{array}{r}46,438 \\
(100)\end{array}$ & 23 & $\begin{array}{r}210,872 \\
(100)\end{array}$ & 146 & $\begin{array}{r}521,255 \\
(100)\end{array}$ \\
\hline
\end{tabular}

注） 1） 本表には航空母艦に改造された戦艦「加賀」，汎洋戦艦「赤城」以外のワシントン軍縮条約によ る建造中止艦艇は含まない。むたアメリカで建造された特務艦「神威」も除外した。なお，航空母 艦「鳳翔」(浅野造船所で船体のみ建造) は海軍工蔽に含めた。

2）「その他」の造船所とは浦賀船渠，横浜船渠，藤永田，石川島，播磨の各造船所と大阪鉄工所， 三井物産造船部をさす。

資料）造船協会編『日本近世造船史一大正時代』（昭和10年)，43-84ヘ・ーシ，日本造船学会編『昭和造船 史』第 1 巻（昭和52年），776-797，818-834ページおよび各社社史より作成。

\begin{tabular}{|c|c|c|c|c|c|c|c|c|c|c|c|c|c|c|c|c|}
\hline た 36 救 & に & に & & の & あ & 上 & の & の & 手 & 面 & & 雑 & 鵠 & 5 & 3 & そ \\
\hline 済 & は & 好 & $こ$ & た & 3 & の & よ & 彼 & と & と & 破 & な & を & 行 & き & $こ$ \\
\hline 融 & & 意 & $\bar{D}$ & め & $た$ & 欠 & 5 & の & L & ब & 綻 & 要 & 身 & 動 & を & ๘ \\
\hline 資 & 郷 & 的 & 松 & $\infty$ & と & 陷 & な & 述 & た & 協 & 直 & 素 & た & $z$ & 利 & \\
\hline 案 & 誠 & に & 方 & 陳 & W & を & 同 & 懐 & の & 議 & 後 & z & 行 & と & 用 & \\
\hline 子 & 之 & 動 & の & 情 & 53 & 回 & 社 & に & は & に & & 8 & 動 & D & L & \\
\hline 閣 & 助 & き & 要 & 学 & & 避 & の & よ & & 入 & 松 & $\hbar$ & で & た & $\tau$ & \\
\hline 議 & 5 & 出 & 請 & 行 & す & す & 特 & る & 海 & 0 & 方 & こ & あ & の & & \\
\hline 了 & に & L & に & な & な & る & 殊 & と & 軍 & た & 幸 & む & כ & で & 政 & \\
\hline 承 & d & & 対 & 0 & わ & 手 & な & & 大 & が & 次 & $こ$ & た & あ & 府 & \\
\hline す & 3 & 早 & L & た & $ち$ & 段 & 地 & そ & 臣 & & 郎 & と & が & る & 力 & \\
\hline る & & $<$ & $\tau$ & の & & & 位 & の & お & そ & は & に & & & & \\
\hline と & & 8 & & で & 彼 & 3 & の & 協 & よ & の & た & な & 結 & & 救 & \\
\hline 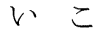 & 成 & 十 & 政 & あ & は & ま & 確 & 議 & び & 際 & だ & כ & 果 & の & 済 & \\
\hline ろ & さ & 五 & 府 & る & 当 & り & 認 & の & 大 & に & $ち$ & た & 的 & $T$ & 融 & \\
\hline ま & れ & 銀 & は & & 初 & 同 & 1 & 内 & 蔵 & 彼 & に & & に & 動 & 資 & \\
\hline で & た & 行 & 海 & & 政 & 社 & & 容 & 大 & が & 上 & & は & は & を & \\
\hline 話 & 三 & 破 & 軍 & & 府 & ح & そ & は & 臣 & 協 & 京 & & & あ & 弓 & \\
\hline を & & 綻 & 定 & & 資 & の & れ & 主 & で & 議 & ] & & 社 & 5 & & \\
\hline 進 & & の & 中 & & 金 & 救 & に & と & あ & の & & & & 佤 & 出 & \\
\hline め & 0 & 一 & 心 & & の & 済 & 伴 & し & 0 & 主 & 関 & & 整 & 味 & そ & \\
\hline$\tau$ & 万 & 力 & に & & 引 & 依 & 5 & $\tau$ & た & 要 & 係 & & 理 & & 5 & \\
\hline v & 円 & 月 & 同 & & 出 & 頼 & 国 & 上 & & な & 諸 & & & $\alpha$ & と & \\
\hline$=$ & の & 後 & 社 & & & で & 防 & 述 & 後 & 相 & 方 & & 複 & E & w & \\
\hline
\end{tabular}




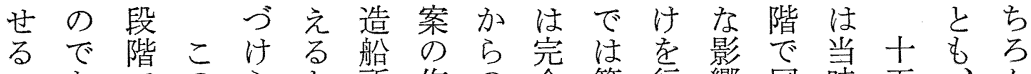
こあでのらと所作の全第行響同時五、ん とるは間れ机成十に五な行華銀同前 に。、のて 政再五は吾ら与株族行社述 なし政政い府建依銀確議こえ式世はにの つか府府た が㤎頼行認会とるる襲、有よ たし 依部と救不さの沙守に性約財明利ら

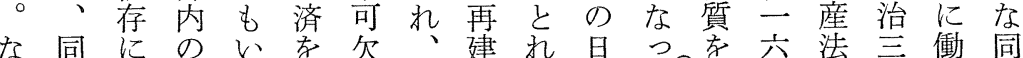

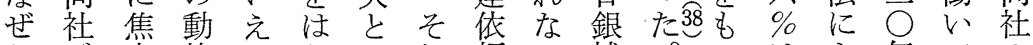
なが点静るかいれ頼い補る。る らこをををと償特て華つ代い特 の絞川こ取あは法に族て同市。殊

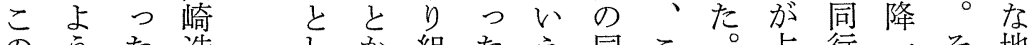
のうた造しか組た方同こ。占行一を地 間に同船たらんこ院のそめ株般机位 同当社所の、芒と川無働こて式銀は学 社初のの同㔔が崎事きでい.㤎行、認 は政対経士社、、救通吕、た華化十め 政府応営五再同こ済過け昭の族要五て 府に策陣 銀建行の案范を和で世進銀い

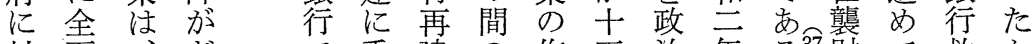

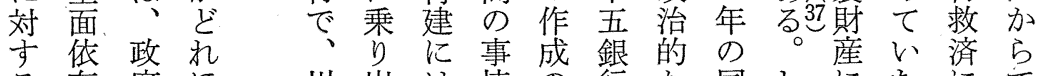
る存府ほ 川出は情の行な同しにたにで 救し 側ど崎し 既を中救圧行た指と対あ 済きの把造て述十心済力破が定は活る 要っ以握船い分とのと綻っさいるが 請た上し 所っょにな代し 時て、卆压、 以このてのたう物つ償て のたて 外とよい救のに語たと展は同いなグう にはうた済で同つ郷し開、行たおいひ

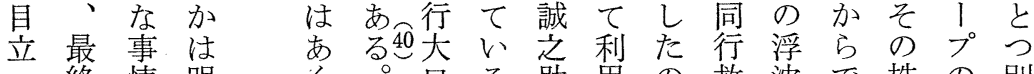
つ終 情明々 口只助用の救沈で株の別 た的のらし貸。古さは済はす主存の 自にながたし彼こ机貴の華あに在要 主はかで 加出はれた族た族つ多で素 的同では五っし最にと院め層た数あ方 整社、な銀ての初乗指でにのがのつ政 理の $い$ 行、三同り摘、華経、華た。府 を整る加再こ○蔵出さ当族済そ族。部 行理一、建の \% 相守れ 時層状の を 内

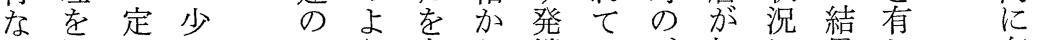
お混のな、一方占ら端々沙相に果し 存

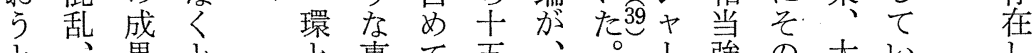

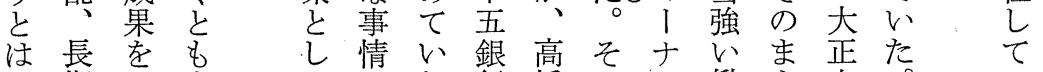

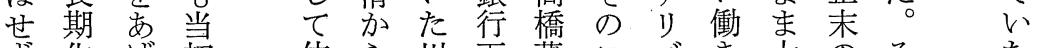
す、华げ初位ら川再蔵こ无き大のそ 置考崎建相と夜き段机こ 


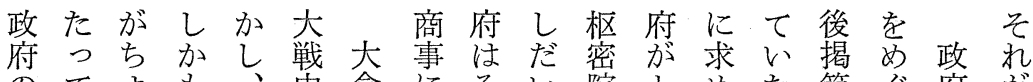
のてょも、中倉にそい院とめた第ぐ府が 決、う先川に鉱よれにを委、机10つは新

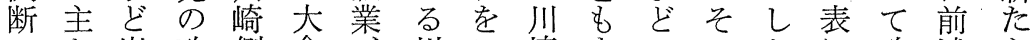
のと出政側倉川向崎まっのかに政述な 重しさ府は両大崎実救きてたしも治の問 要てれ 救破社 倉 造と済こいめ的問よ題 な問た 済綻か商船しにみるる、同る題うる 因題大案後 5 事所て対、間当行よ肪に発 子に阪にも買の少的最に初のう発、生 とし控 はな以两士 崎て終、順側に生早さ

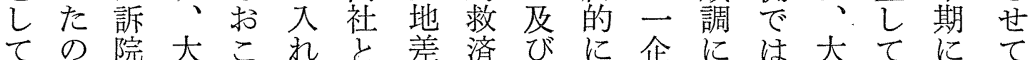
働はの倉のた押加腰澲進川蔵き川政

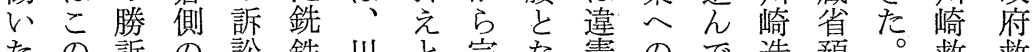
たの訴の訟 鉄川と完な 憲の で造預。救 救 事判こに納崎国全つ問国い船金そ済済 こ件決の対入造際にて題家た所部の案の れでを訴し代船汽手いに資川の資口学停 はあ基訟て 金所船をつま金崎将金火閣止

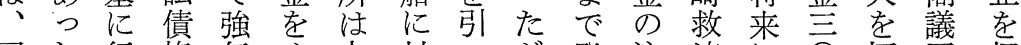
国た行権気め大対い阮発注済に可了招

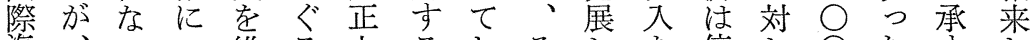

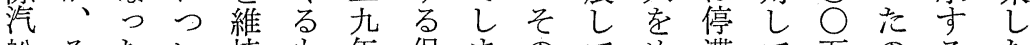
船そたい持も年保まのて がれのてしの以証つよいぐを強円はと加

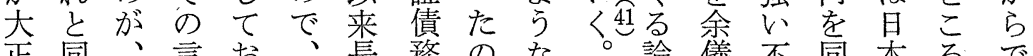
正同、言拉、長務のな。論義不同本乃年 末時上及り、実期ので時そ議な安行興まま

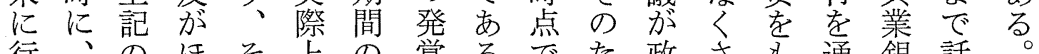
行、のほそ上の覚る。でた政さむ通銀話

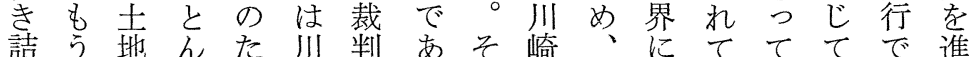
つひ差どめ崎をつの造一起しお川ああ たと押な大に行た際船度こまり、崎つて 際つえか倉不なっ所はつっ、造た のでつ側利つ 銀国あたのなて 行際つた心内い 借汽た先め, 証容た 入船孝の れへ政こき訴こ にの府れわ訟れ よ保肪にめ事は 証 救反

て債済発，害で同 笨務打ししあ社 境の切たてつが を発り大いた第 打覚に含た開市立次 問を川てたこ船学た 題め崎い。の所 政 が とぐ救っし貸に府 なる済た か出貸㤎こ たう案をを索を出承前 のの閣のこ伴すし後 は事議結のうとたに 大件了果興損 倉肪承、銀失 う済の 鉱起しこの保点案 政 業こたの这証にの府 り 政 論対を㧤骨の 大、府議に政加子方 倉政守政府れは針 
もてそ点をるなな゙でな同あいし あいのの取状政かわ局こた ったら同り況府ら机面らと実拄自っ当ら た社ち社消は救でて打しいをざらて時と 船のにさ、済あい開で年りのいにし しと一とれ破のるっを手明おた かの隻っ、綻打。たは川うてしで確い時 し関をて ま当切自か崎。した解にて点

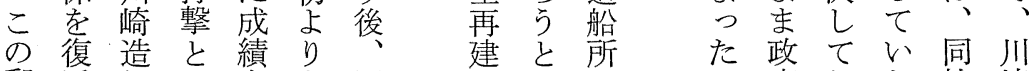
郵活船な良も同のむお府おな社崎 船し所つ化ま社過て当汀に加肪造

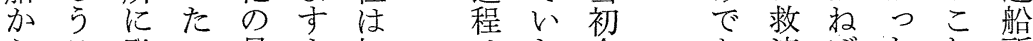
らる発の見ま初はた全済ばたれ乺

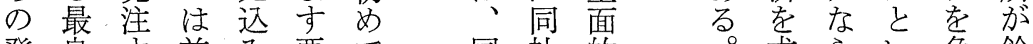
発良专前

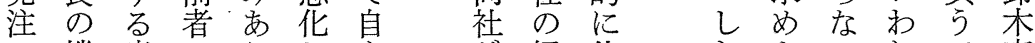

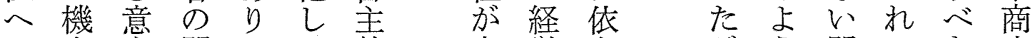
の会向問とて整大営存驾う問て き店 期でを題さい理 正戦し つと題い義と

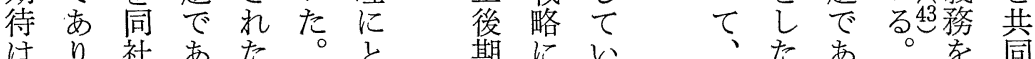

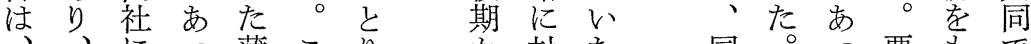

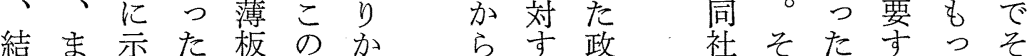

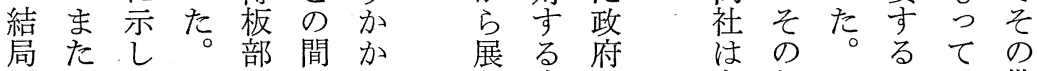
同肥て旦朋につ開決加自たしにい借 社大

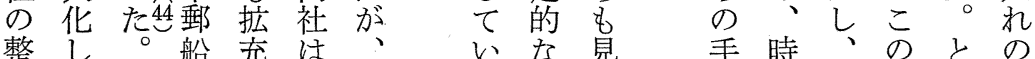

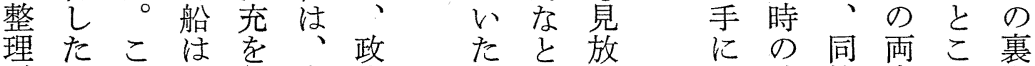

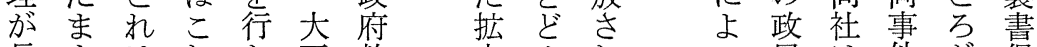
長まはれな正救大めれる局は件が、保 期維川よい末 化持崎りえにに略意し なる れも同を 寸し造先な内い, の味ま政から社し るて船、意っ 完しつ府での破はて なき所大ま孝さ全てた市閳綻こい かたと正ま受いないがなら題後のた で造し末にけを否た、腰を政保も 船てになて託定。こ救と二府証の

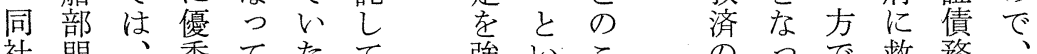
社門を秀て た

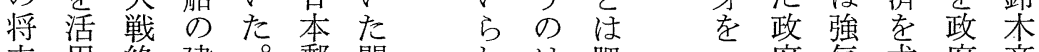
来用終建。郵間机肥胫府求府商 にし了造特船にるる みににめ店 不与後をに古同過こ化と救出る資吕 安る長企、ら社程れし済段料破 機く図このををで以た打他階提綻

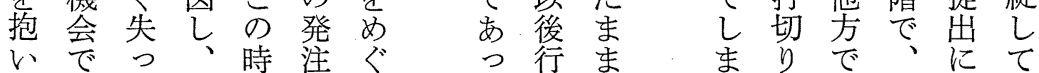


経 営史 学

第10表 川崎造船所に対する政府救済案と最終整理案の対照表

\begin{tabular}{|c|c|c|c|}
\hline \multicolumn{2}{|c|}{ 内 容 } & 政 府 救 沙 & 最 終 整 理 案 \\
\hline $\begin{array}{l}\text { 旧 } \\
\text { 債 } \\
\text { 矢 } \\
\text { 損 } \\
\text { 処 } \\
\text { 処 } \\
\text { 理 } \\
\text { 法 }\end{array}$ & $\begin{array}{l}\text { 資 本 金 } \\
\text { 末払込金 } \\
\text { 欠損処理 } \\
\text { 供入金処 } \\
\text { 分 }\end{array}$ & $\begin{array}{l}\text { ○半減 } \\
\text { ○切捨て } \\
\text { ○半減した資本金と積立金に } \\
\text { よる償印 } \\
\text { ○無担保分一 } 7 \text { 割を優先株に } \\
\text { 振替え, } 3 \text { 割を払い戻す } \\
\text { ○有担保分一担保物権の処分 } \\
\text { による償却 } \\
\text { ○該当項目なし }\end{array}$ & $\begin{array}{l}\circ \text { 無担保債務・社債一昭和 } 5 \text { 年 } 4 \text { 月以降毎 年 } \\
300 \text { 万円以上を按分して償還。昭和 } 13 \text { 年 } 3 \text { 月 } \\
\text { に完済のこと } \\
\circ \text { 有担保分一利子の軽減を想請。担保物件の処 } \\
\text { 分により決済すること } \\
\text { ○原則として年 } 7 \text { 分 (昭和 } 3 \text { 年以降 } 3 \text { 年間は } 6 \\
\text { 分 } 5 \text { 厘) } \\
\text { 。延滞利息一年 } 7 \text { 分, 昭和 } 3 \text { 年 } 12 \text { 月までに弁済 }\end{array}$ \\
\hline $\begin{array}{l}\text { 新 } \\
\text { 嫢 } \\
\text { 借 } \\
\text { 金 } \\
\text { の } \\
\text { 処 } \\
\text { 理 }\end{array}$ & $\begin{array}{l}\text { 借 入先 } \\
\text { 金 額 } \\
\text { 債 務 者 } \\
\text { 抵 当 }\end{array}$ & $\begin{array}{l}\circ \text { 日本興業銀行（大蔵省預金 } \\
\text { 部資金を融通） } \\
\circ 3,000 \text { 万円 } \\
\circ \text { 川崎造船所 } \\
\text { ○工場財団設立による一番抵 } \\
\text { 当権設定 }\end{array}$ & 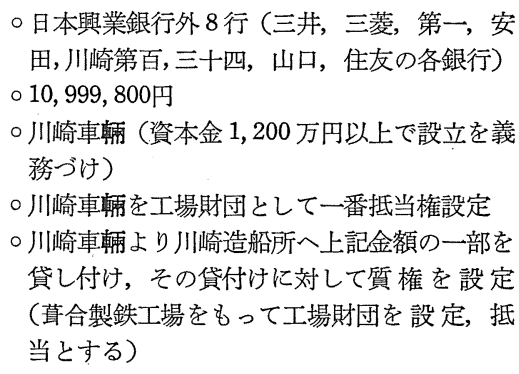 \\
\hline $\begin{array}{l}\text { 付 } \\
\text { 随 } \\
\text { 義 } \\
\text { 務 } \\
\text { 事 } \\
\text { 項 }\end{array}$ & $\begin{array}{l}\text { 重役選任 } \\
\text { の制限 } \\
\text { 財産処分 } \\
\text { の制限 } \\
\text { 会計監查 }\end{array}$ & $\begin{array}{l}\text { っ当社長と取締役一部の更迭 } \\
\text { （選任制限には言及せず） } \\
\text { ○該当項目なし } \\
\text { ○該当項目なし } \\
\text { ○該当項目なし }\end{array}$ & 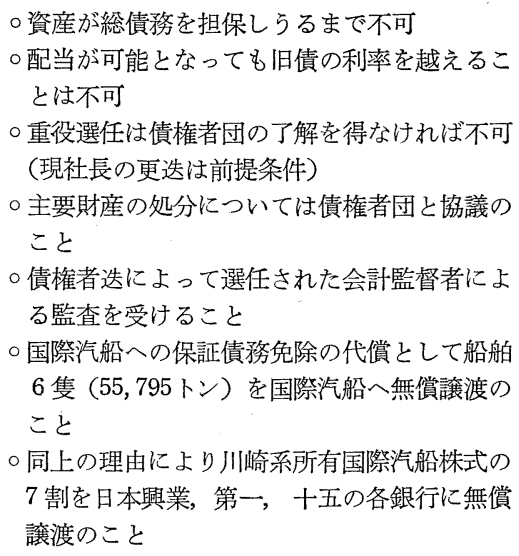 \\
\hline
\end{tabular}

注）政府救済案は郷誠之助の立案によるもの。「最終整理案」は昭和 3 年 4 月に倩権者団と川崎造船所との 間で締結された協定を中心に，昭和 2 年12月に同社と日本興業，第一，十五の 3 銀行との間に締結された 国際汽船保証債務についての協定内容を加えたものである。

資料）郷男爵記念会『男爵鄉誠之助君傅』545-546ページ,川崎重工業株式会社藏「和議関係資料」および 『川崎汽船五十年史』68ページり作成。 


\section{川}

\section{t}

だ

\section{ぞ}

\section{き}

経

罯

の

変

化

見

わ

兑

そ

経

嫦

戦

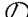

行

y

に

面

た

そ

全可触觬こた。川余た轄こや限上運た 銀必㭴とそ崎をの移の界海賴本 行要つつはの造なの守よにの金郵 管といい、さ船く、こ達所金船 理守てて同い所しことなし有供唯 捛のるのも表締とてので同て地給内 わもな跾優に結債いよ社いをを定

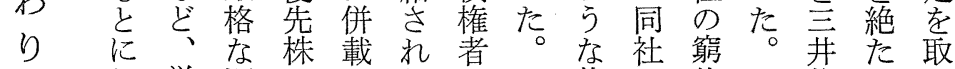
飞抒䇴返へした扔状の状物れり か格済のた整よ況完に産た消

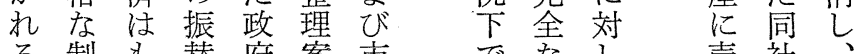
る制も替府案市でなし売社

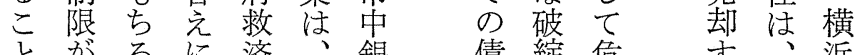

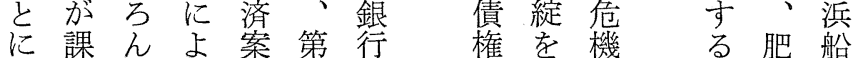
なさのっを 10 団者喰感等大溇 つれこて比表と団い学白化に たてと、較にの就止を手しそ

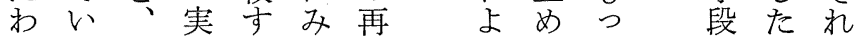
ける経質れら建れびよた浩を での営的ばれ交市ら海よ船振 あで権な明る渉中と軍つ部り るあにならよ䜑銀しははて門替 るつしから最行た稀運をた 要方字に終団兄転維た

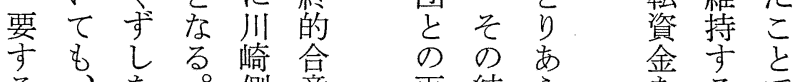
る、を。側意再結光孝るで にたはすに华建果夺得途潰 、少なき達交昭存え こえるわわし渉同和い完さ のばらちめたは社三た全っ

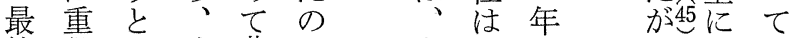
終役し 政苛は当少七、断し 整のて府酷、然な月年なた 理選い案な昭 のく机っ

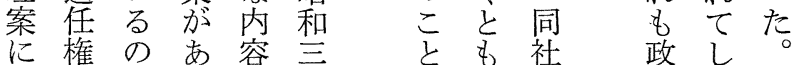
に権の市容年文最社整まそ つ財対ます四し悪造救うの て産しでっ月元船済。た 、処て資たに事部打しぬ 同分、金导入崎態鹏切加 社権最供のつ 側だの 号も十 はに終給でてのけ一前こ五 ほ債整を学意は部後の銀 と権理中っら向避を部間行 ん者案心たでの海は品 どのでと。あ通ら軍军同ら

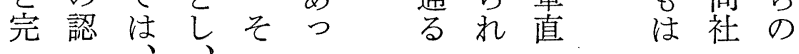




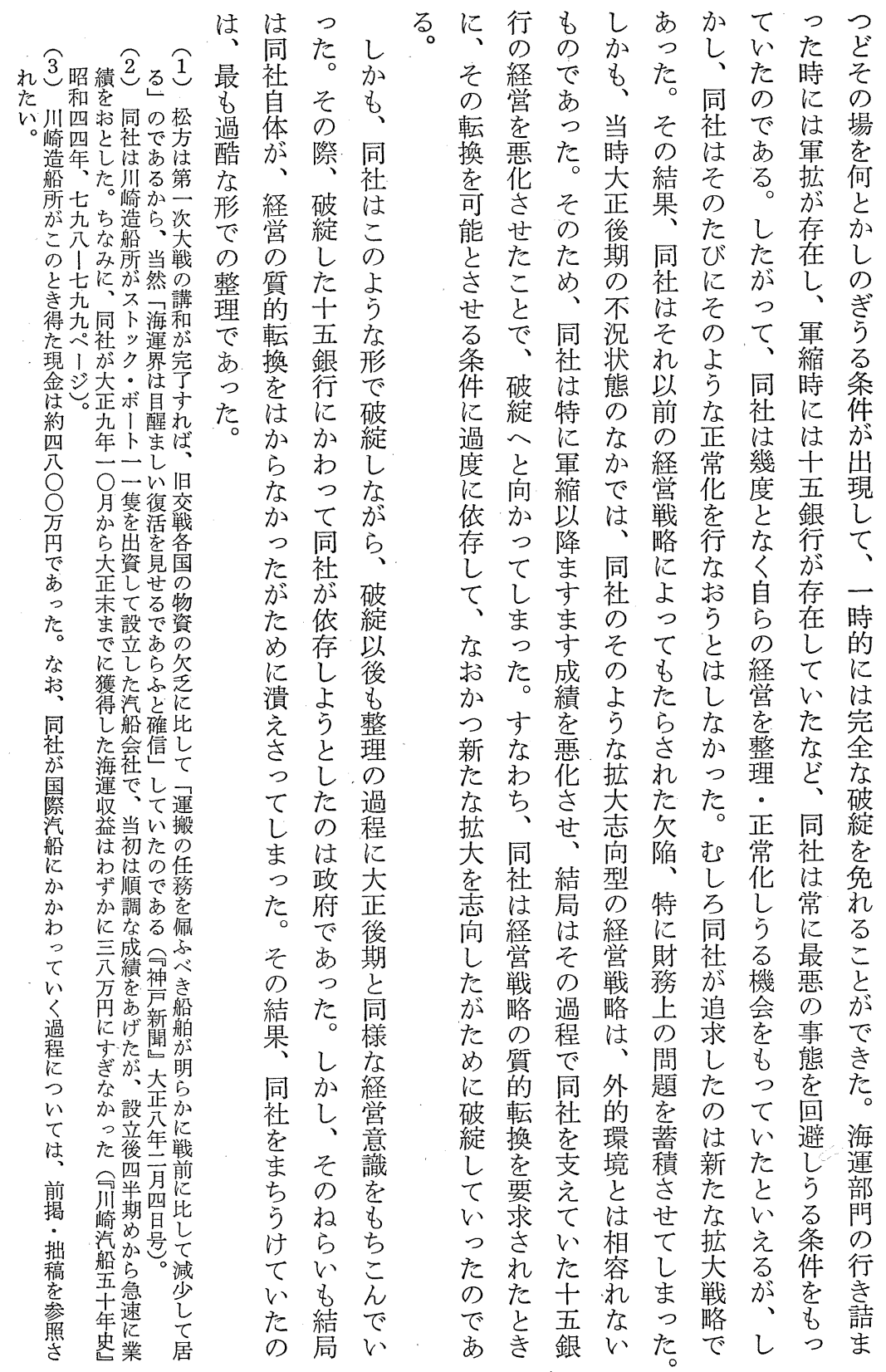




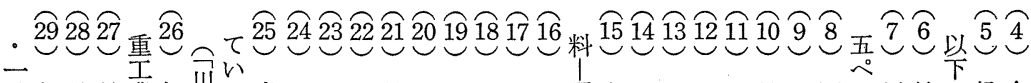

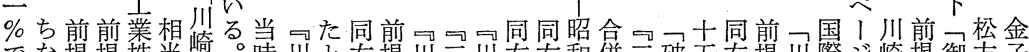

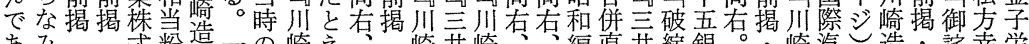

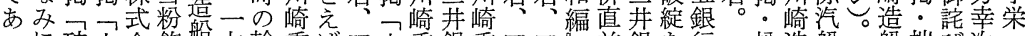
っに破十会飾船方輸重ば四十重銀重四四管銀を行 た当綻五社加所川大王的五王行工八刀第の行暴の 時点銀社加果崎薄業東四銀業八業四三三同八露大 十の暴行史え造板株洋へ行株十株へ。四行十乚正

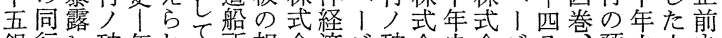

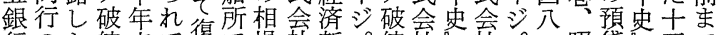
行のた䋎表て復で場社新。䋎社鱼社。四昭貸苾五で 各対十原・以活のは社報 期払五因諸る出同二史包 営込銀及表之来種三岕大 業资行其整三考名製枚六正 告金二理吾営二可原で九年

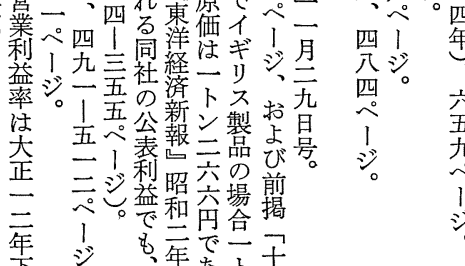
原社五社へ和率五銀の 因史五史!四は吾行状 及足吾浯四九志況 其六五昭

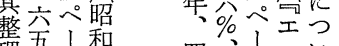

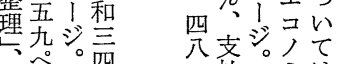

松造船 船拙び次一 方船は所稿の郎編 幸所大第正記一御第現 郎五末録 ○拶六代

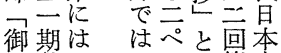
詫嫦ほ三1略第産 び業と杂渻。記公業 の報え 隻。卸告ど発 挨書破年定史 拶星、产時 IX

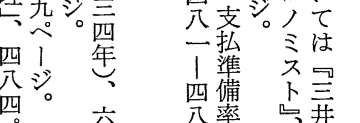
公率品茀 三圭 昭銀 脑\% 年年

$\begin{array}{ll}\text { あ } & \text { 五史 } \\ \text { た } \\ \text { 昌照 } \\ \text { 号和 }\end{array}$

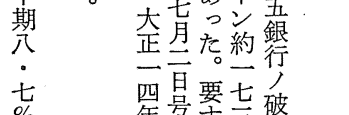

\% 年号守要破

銀 三主

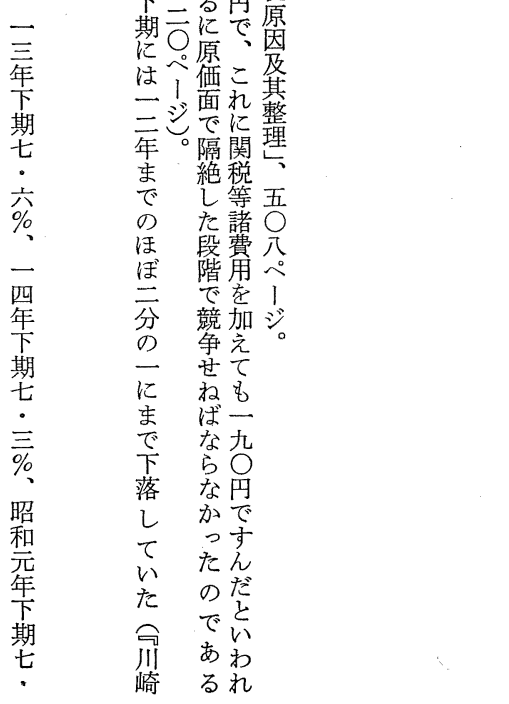

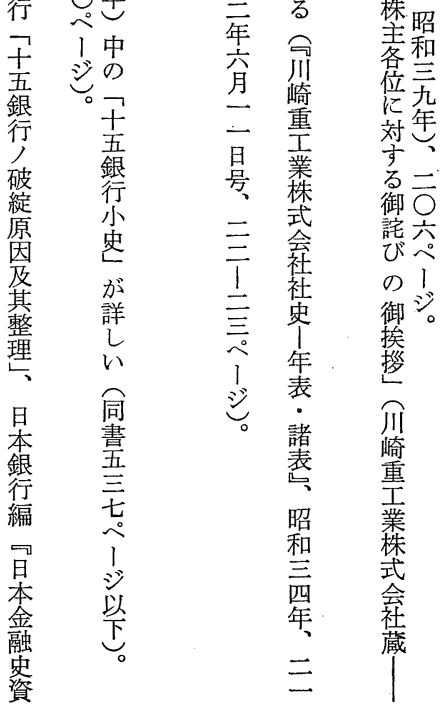




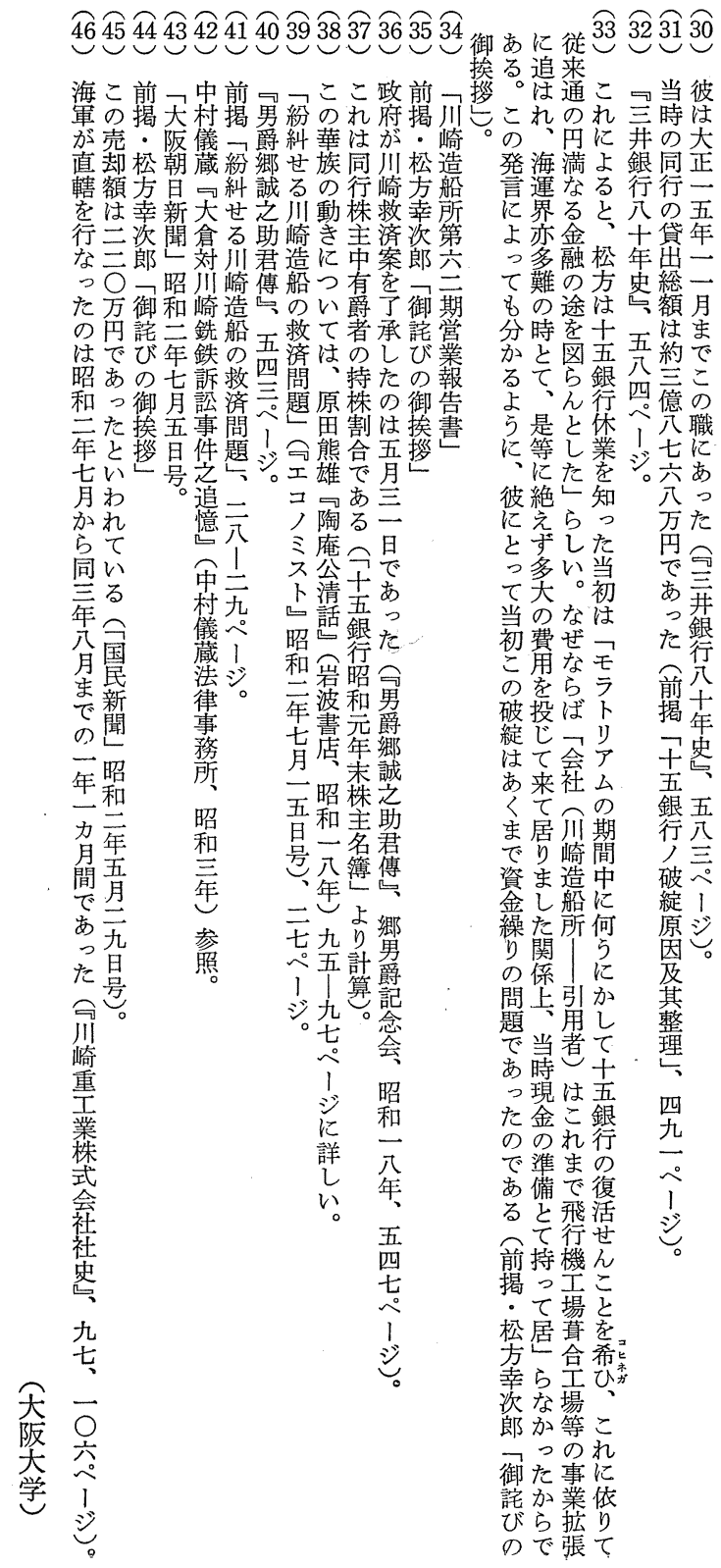




\title{
THE COLLAPSE OF BUSINESS STRATEGY AND ITS SETTLEMENT IN THE MONETARY CRISIS
}

\author{
Takao Shiba
}

From the second half of Taisho Era to the beginning of Showa Era, many firms loosely carried out strategies for expansion and for that reason they collapsed. Kawasaki Dockyard Co., Ltd. was a typical case of them.

The company had acquired huge profit during the First World War. But its management became worse in the second half of Taisho Era, because the company excessively carried out strategies for expansion in the depression. Moreover, in the process, the company excessively depended on its main bank. This bank was Jūgo Bank. Therefore, when Jūgo Bank had collapsed in the Monetary Crisis in 1927, Kawasaki Shipkyard Co., Ltd. collapsed too. The process of this collapse of the company was a typical case of many management collapses in this age. However, the process of settlement of the company differed from those of other collapsed firms. Because the company had an important position in the Japanese national defense program, and Jūgo Bank, the main bank of the company, too had special position in the Japanese financial circles.

This article traces this process of the collapse and settlement in Kawasaki Shipyard Co., Ltd.. 